\title{
Kingdom on the Beach Ridges: A Landscape Archaeology of Tambralinga in Peninsular Siam
}

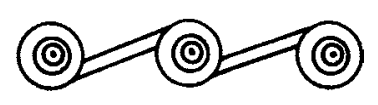

WANNASARN NOONSUK

\section{INTRODUCTION}

Peninsular Siam, or Southern Thailand, the northern part of the Malay Peninsula, is an isthmian tract between the South China Sea and the Bay of Bengal (Fig. 1). It has been an important crossroad of civilizations since the mid-first millennium B.C. Unlike the lower part of the Malay Peninsula, which was heavily forested and almost impossible to cross, the isthmian tract was a thin ribbon with relatively narrow mountain ranges in the middle. A series of transisthmian routes comprised of rivers and walking trails provided passageways between the west and east coasts.

There is significant evidence that coastal communities in peninsular Siam were part of an intraregional long-distance exchange network in maritime Southeast Asia. Local communities circulated their resources and goods prior to the integration of this region into the greater trans-Asiatic trade network. For example, a number of Dong Son bronze drums and lingling-o earrings dated to around the first half of the first millennium B.C. and emanating from coastal Viet Nam were found in peninsular Siam, indicating that an intraregional exchange network centered in peninsular Siam may have provided a key geographic focus for the emerging broader maritime transAsiatic trade network more than two millennia ago.

Since at least the mid-first millennium B.C., a maritime trans-Asiatic trade network developed and expanded, linking vast regions of the ancient world, including, but not limited to, the Mediterranean world, the Middle East, the Indian subcontinent, Southeast Asia, and China. This network seems to have been comprised of a number of regional but overlapping interaction spheres. The one that was most influential to communities in peninsular Siam was the sphere in the Bay of Bengal wherein the cultural connections between the isthmian tract and the east coast of India were intensified. The archaeological sites of Phukhao Thong (Chaisuwan 2011) and Khao Sam Keao in the northern reaches of the isthmian tract have provided evidence of possibly the earliest phase of social interactions between the two regions in the mid-first millennium B.C. (Fig. 2). These sites yielded a considerable number of semipreciousstone and glass beads, as well as ornaments, gold objects, and pottery. Some of them

Wannasarn Noonsuk, Ph.D., is Head of the Research Unit for Archaeology and a Lecturer in the Ph.D. Program in Asian Studies, Walailak University, Nakhon Si Thammarat, Thailand. 


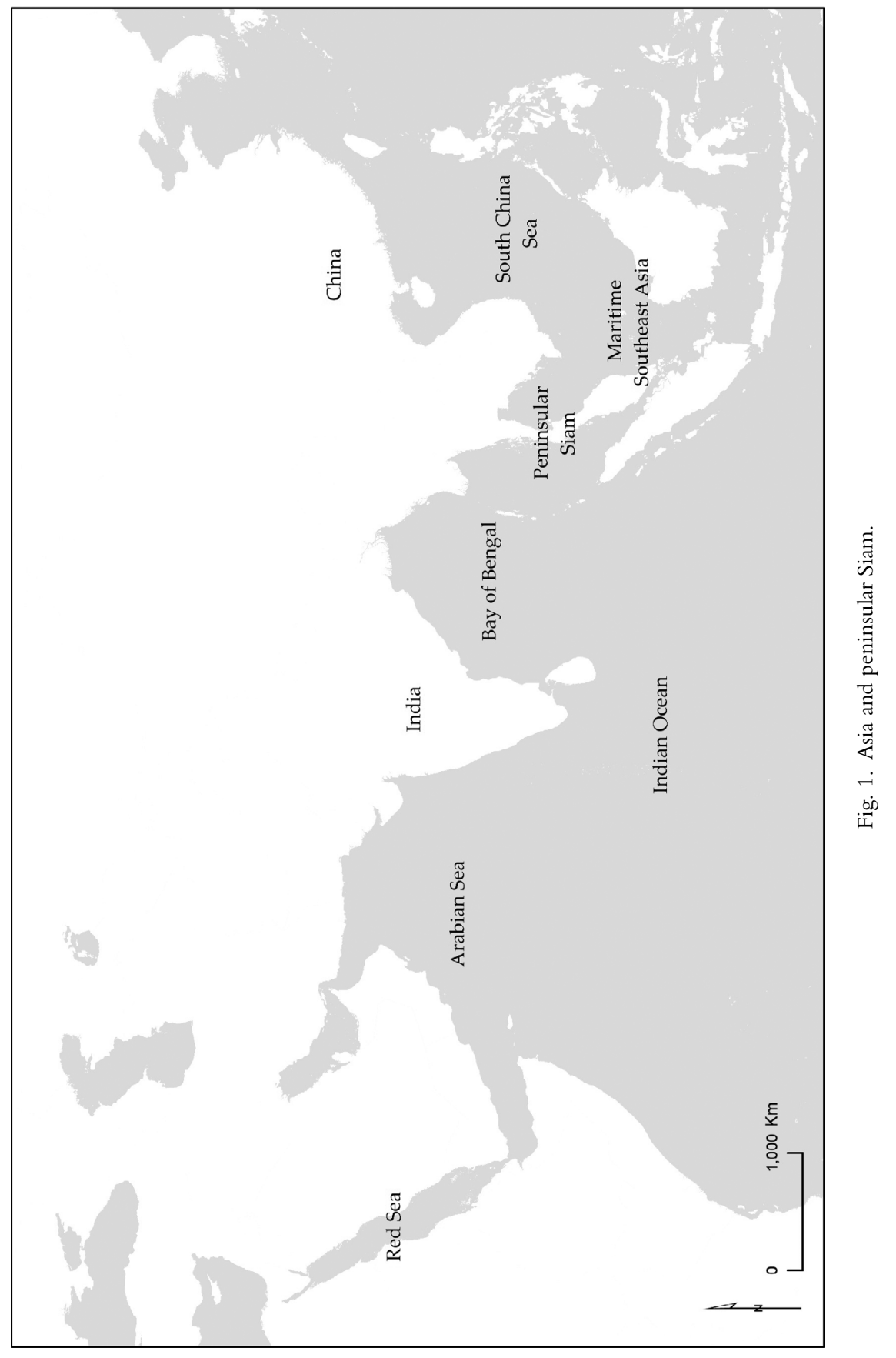




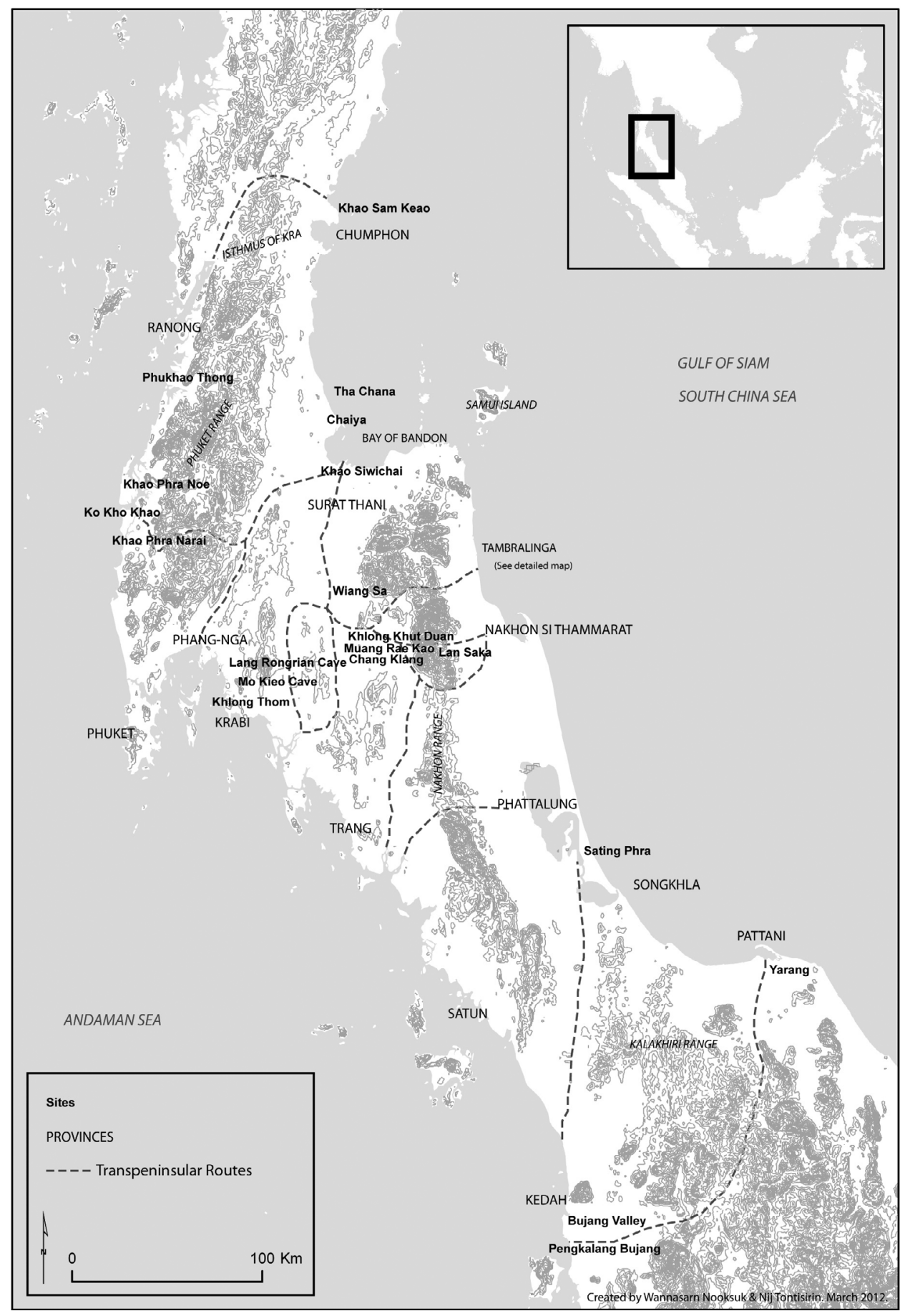

Fig. 2. Peninsular Siam, provinces, possible transpeninsular routes, and archaeological sites. 
may have been imported from India, while others were produced at these sites using Indian technologies. Evidence for the latter is in the raw materials, unfinished products, and production debris recovered archaeologically from the sites, especially Khao Sam Keao, which has been carefully studied by Bellina-Pryce and Silapanth (2006). Two other sites have yielded obvious evidence of local production of beads and jewelry along the isthmian tract, including Khlong Thom (a.k.a. Khuan Luk Pat) and Tha Chana (Fig. 2). These may possibly date to a later period, around the early centuries A.D. A number of Indo-Roman intaglios were also found at Khlong Thom (Chaisuwan 2011; Veeraprasert 1992).

Local populations in Southeast Asia in general and peninsular Siam in particular seem to have played an important role in both the production of goods and the transport of both local and exotic goods within this maritime trade network. The fact that trade goods such as beads were found at interior sites in the mountain areas at the middle of the isthmian tract (including Rai Nai situated east of Phukhao Thong) suggests that local people who had intimate knowledge of their geography facilitated the transportation of these goods across the isthmus; they may have been consumers of these goods as well. Chinese historical records of the period mention that people in this region were collectors of valuable forest products and skillful marine and riverine navigators, which would have been crucial to trade activities (Manguin 2004; Wheatley 1966:16).

The maritime trans-Asiatic trade not only facilitated the flows of people, goods, and ideas within its interaction network, but was also a catalyst for the economic and sociopolitical development of societies in the isthmian tract, which contributed to the emergence of relatively complex societies in this area (Glover 1990). Maritime trade, coupled with other factors such as intensified agricultural production on a scale capable of supporting specialist forest product collectors, craft producers, traders, and trading and political administrators, enabled the Tambralinga Kingdom to emerge on the east coast of the isthmian tract in around the mid-first millennium A.D. The heartland of this kingdom was located on the coastal plain of what is today Nakhon Si Thammarat Province.

Although historical documents have enabled scholars to appreciate the regional economic and political importance of this kingdom, its archaeologically evidenced cultural landscape has been little studied. Recognizing that familiar rhythms, styles, and patterns of life arise from the possibilities offered by a landscape (O'Connor 2013:xii), this article aims to explore the cultural geography of the Tambralinga Kingdom, including how land, sea, and human lifeways were interrelated. It explores the cultural development and geography of Tambralinga based on data gathered with a variety of methods, including archaeological survey and excavation, GIS-based mapping, and ethnographic interviewing. ${ }^{1}$

Cultural geography is the study of the relationships between people and their environment. The environment includes not only natural settings but also social settings and other cultural elements that shape and give meaning to geography from past to present. Thai scholar Srisakara Vallibhotama proposes that cultural geography should be defined as the study of geographical landscape as it relates to people's lives and habitations, including how people or groups of people in the past interacted with one another, with their environments, and with supernatural powers (Vallibhotama 2008a, 2008b:7-10; 2008c:10, 23). He notes that human populations in traditional societies have everywhere changed their natural spaces into cultural spaces by constructing 
myths to explain the meanings and significance of their localities. This view concurs with that of Nithi Aieosriwong, who postulates that humans place all real and imaginary things, and relationships between them, into spaces and times they have themselves constructed. By doing so, humans give meanings to the things of their world, and their worldview is based on their conceptions of space and time (Aieosriwong 1995 : 132). Natural space therefore becomes part of the cosmology of local communities; it ties people together in society and establishes social rules for the relationships between an individual and society, natural resources, and some form of supernatural power.

In cultural geography, landscape has been constructed, inhabited, and imagined by groups of people from past to present (Stark 2006:1). Landscape is a cultural product created and understood in a social context. People culturally transform physical spaces into meaningful places (Anschuetz et al. 2001:158) that are sometimes imbued with political statements (Smith 2003). Although the landscape is shaped by human agents, it also shapes and influences its human inhabitants. It has its own agency, creating impressions in people's minds and ways of imagining their experiences. Paul Devereux (2000:19) draws several strands of scientific and humanistic data together to propose that a sense of place is a mental phenomenon partly generated within the human mind and partly provoked by a place itself. He examines the Greek concept of space that includes two words: topos, meaning the physical aspects of a place, and chora, a mysterious, less passive property of space that has a more subtle and poetic quality than topos. He notes "when we consider chora, place becomes an agent that provokes our sensibilities, that can stir the seeds of spirituality within us" (2000:19). In the same vein, Stanley O'Connor (1974:71) mentions that caves and high places had a very strong impact on the religious imagination of those who lived in peninsular Siam in the past. He wrote that "the sedimentation of long memory together with the compelling brute presence of twisted pinnacles allowed the landscape to speak and be read as a system of the language of changing formal religious intention" (O'Connor 1974:71). While earth and water were related to the supernatural power of the underworld, high places were related to the supernatural power of the celestial domain and cosmic forces (Vallibhotama 2008c:46). People in peninsular Siam in the past placed votive tablets in the caves and built monuments on the hilltops. This signified the power of the place in people's experience and the attempt of people to make sense of their world through imagination and materialization.

\section{BRIEF HISTORICAL BACKGROUND}

Historians usually tend to start their in-depth discussions about Tambralinga as if this kingdom emerged only in the eleventh or even the late twelfth century (e.g., Jacq-Hergoualc'h 2002:391-442; Sumio 2004). This is not surprising because most detailed historical accounts available to us about this kingdom date from the late twelfth to the fourteenth century, the time when this kingdom was very actively intertwined with the larger history of South and Southeast Asia. As mentioned in the local historical documents of its heyday in the thirteenth century, Tambralinga (i.e., Nakhon Si Thammarat) sent several envoys to the Chinese court, acted as an important center for ceramic trade in maritime Southeast Asia, and even launched an armada across the Bay of Bengal to attack Sri Lanka, where it ended up occupying the northern portion of the island (Sumio 2004:54). However, the early history of 
this kingdom has been little studied from either historical or archaeological perspectives, particularly not through the cultural geography approach outlined here.

Tambralinga is a Sanskrit name that has a variety of meanings, translated into something like "Red Siva Linga" or "Copper Siva Linga." Both these translations signify the prominence of Saivism in this kingdom. As far as we know, Tambralinga was a polity that thrived on the growing network of the maritime trans-Asiatic trade. A second or third century A.D. Indian text, Mahanidesa, mentioned that a place named Tamali, which is believed to be Tambralinga, was a destination of Indian merchants (Wheatley 1966:180). Chinese accounts of around the same time did not mention the name at all. The Chinese record does, however, vividly describe several other polities on the isthmian tract in the first millennium A.D. According to the Chinese accounts, countries neighboring Tambralinga shared similar forms of sociopolitical complexity, engaged in similar types of foreign maritime trade, and similarly adopted Indic religions, so they may offer us some clues about the character of Tambralinga itself. According to the Chinese accounts, some isthmian polities from the first century B.C. were already profiting from the maritime trade between China and India, and, at least by the third century A.D., both Buddhism and Hinduism were well established in their lands (Wheatley 1966). These Indic religions underwrote state rituals and royal display. This may have been the sociopolitical and economic environment in which Tambralinga flowered.

The name "Tambralinga" has perhaps the longest history of toponyms in peninsular Siam. It first seems to have appeared in the Indian Mahanidesa text of the second century as Tamali, and perhaps last appeared in the Chinese Dao-yi-zhi-lue text of 1351 as Dan-ma-ling (Sumio 2004:52). This means that the name existed for around twelve centuries. Neither the Indian nor Chinese texts offer much information on the precise location of this polity, but based on studies of local stone inscriptions and archaeological remains, most scholars agree that Tambralinga was located in the coastal plain of Nakhon Si Thammarat Province (Noonsuk 2001; O'Connor 1986b; Wolters 1958). In the thirteenth century A.D., Tambralinga reached its peak in terms of economic and political powers; it was also called Nakhon Si Thammarat, a name related to the dominant religion of the kingdom at the time, Theravada Buddhism. It was then annexed by the powerful kingdom of Ayutthaya (from the Chao Phraya River basin) in around the fifteenth century.

\section{SITE DISTRIBUTION IN THE HEARTLAND OF TAMBRALINGA}

The heartland of the Tambralinga Kingdom is an almost rectangular area covering $1275 \mathrm{~km}^{2}(127,500 \mathrm{ha}): 85 \mathrm{~km}$ long in the north-south direction and $15 \mathrm{~km}$ in the east-west direction. It is flanked by a mountain range in the west and the sea of the Gulf of Siam in the east (Fig. 3). Its northern reach is at the Phlai Dam Mountain, between Khanom and Sichon districts, where the smooth coastal plain is interrupted by a group of mountains and hills before reaching the Bay of Bandon; its southern limit would seem to be the Sao Thong river, beyond which the archaeological record thins out.

The coastal lands of Nakhon Si Thammarat Province were mostly formed by the accumulation of erosions from the Nakhon Si Thammarat mountain range (colluvial and alluvial deposits) and by the movement of waves in the Gulf of Siam (coastal wave-dominated deposits). The colluvial and alluvial deposits closest to the Nakhon 


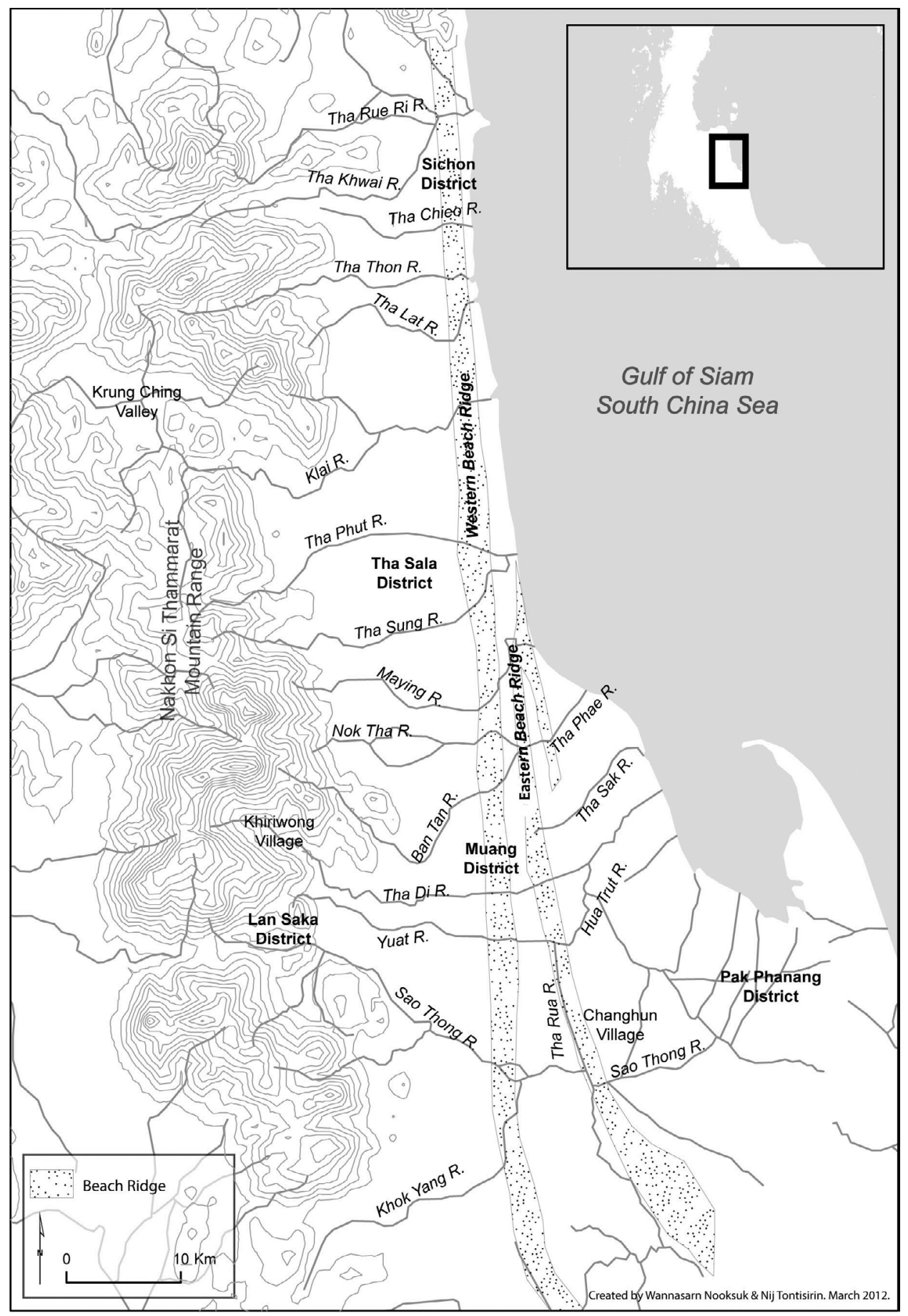

Fig. 3. Geography of coastal Nakhon Si Thammarat, the heartland of Tambralinga. 
Si Thammarat range were formed in the Pleistocene epoch $(2,588,000-11,700$ years B.P.). This area was fertile and suitable for rice cultivation and orchards. The coastal wave-dominated deposits were marked by the formation of beach ridges during the maximum transgression of sea water in the years 8000-6000 B.P. After that, the sea started to retreat and formed new sandy beach ridges running parallel to the older one in the north-south direction (Suphawajruksakul 2005:19-23). The waves moved northward along the east coast of peninsular Siam, carrying sands and forming the coastal land east of the oldest beach ridge (Midas Consultants 1996:1). Evidence of this can still be seen in the geomorphology of the Talumpuk spit in the Pak Phanang district of Nakhon Si Thammarat Province and the Ta Chi spit in Pattani Province. These ancient beach ridges are a very important geographical feature in the settlement pattern in this area. They provided coastal high ground that would not normally be flooded in the rainy season and also served as highways for communication along the coast.

Two prominent ancient beach ridges in coastal Nakhon run in the north-south direction (Suphawajruksakul 2005:26) (Fig. 3). They are 2-5 $\mathrm{m}$ high and $1-5 \mathrm{~km}$ wide. These two beach ridges are almost joined to form a bident shape, with a long handle descending from north to south and two prongs breaking away from, but still running parallel to, one another. The ridge on the west is older than the east. It was the shoreline around 6000 years ago, and is still very close to the present shoreline in the northern portion of the heartland from the estuary of the Tha Sung River northward. It runs from the northern end of the heartland of the region at Khao Phlai Dam Mountain in the Sichon district to the Cha-Uat River in the Cha-Uat district. It is approximately $120 \mathrm{~km}$ in length. The Cha-Uat River seems to be a remnant of the massive ancestral river that ended this beach ridge and helped create the large, fertile floodplain on the old tidal flat east of the beach ridge, the so-called Pak Phanang River basin (Suphawajruksakul 2005:35). The widest distance from the present shoreline is about $40 \mathrm{~km}$ at Cha-Uat. This is the "western beach ridge" referred to in this study.

The second beach ridge is younger than the western beach ridge. It was a long submarine barrier when the western beach ridge was the shoreline, but when the seawater retreated sometime after 6000 years ago, it emerged and became a new shoreline (Suphawajruksakul 2005:35). It runs around $65 \mathrm{~km}$ in length from the delta of the Tha Sung River to the Cha-Uat River (or the Karaket River, as it is called in that area) in the Chian Yai district. The longest distance from the present shoreline is about $30 \mathrm{~km}$ at Chian Yai. The distance between this beach ridge to the western one ranges from 1 to $10 \mathrm{~km}$. They are closer to each other in the north and then move away from each other as they descend southward. This will be referred to as the "eastern beach ridge."

The eastern beach ridge was important in the establishment of the kingdoms of Tambralinga and Nakhon Si Thammarat. In the thirteenth century, it was called Had Sai Kaeo, or Crystal Sand Beach; it was a sacred place on which the capital city of the Nakhon Si Thammarat Kingdom was founded. According to the Chronicle of Nakhon City, a Buddha relic was buried there and it is where the Great Reliquary of the Wat Mahathat stupa was constructed (Wyatt 1975:66-77).

The Nakhon Si Thammarat mountain range called Khao Luang is a high, dense range that forms the backbone of peninsular Siam. Its peak, Yot Khao Luang, rising $1835 \mathrm{~m}$ above sea level, is the highest mountain peak in the isthmian tract. This was 
probably used as a prominent landmark for maritime navigation to Tambralinga. The Nakhon Si Thammarat range acts as a massive wall, ensuring that moisture carried by the northeast monsoon will become rain providing plenty of water to the coastal plains of Nakhon Si Thammarat. It rains there roughly nine months a year from May to January, under the influence of monsoon winds. The average rainfall is $1922 \mathrm{ml}$ per year. It is one of the wettest areas in Thailand, and barely experiences a dry season.

A number of short rivers flow from this range to the coastal plains and the Gulf of Siam, leaving fertile alluvial deposits on the flat plain before cutting across the beach ridge to the sea. During the rainy season, the area behind the beach ridge floods, acting as a natural dam containing water before letting it go to the sea. Although seasonal flooding is usually short-lived because of the many rivers channeling water to the sea, it leaves sufficient alluvial deposits on the coastal plains to provide perfect support for wet-rice agriculture.

Tambralinga's heartland area has been occupied by people since the prehistoric period. There are some Mesolithic sites (12,000-5000 B.P.) in the mountain areas, and perhaps one on the ancient beach ridge at the site of Ban Bang Phan Sai (Noonsuk 1997:81). The cultural chronology in the coastal land most clearly starts with the Neolithic period; tentative time periods are as follows:

1. Neolithic period (2000-500 B.C.)

2. Iron Age (500 B.C.-A.D. 400)

3. early Tambralinga period (c. fifth to eleventh centuries A.D.)

4. late Tambralinga/Nakhon Si Thammarat period (c. twelfth to fourteenth centuries A.D.)

5. Ayutthaya period (c. fifteenth to eighteenth centuries A.D.).

These are only five approximate time periods because only a few scientific dates exist (i.e., ${ }^{14} \mathrm{C}$, AMS, or TL dates), especially for the periods before the late Tambralinga period, for archaeological sites in this area. These periods are quite broad and require more precision, gained through more detailed studies of stratigraphy, microstylistic analysis of artifact and construction forms, and the liberal use of absolute dating methods, if archaeologists are to be successful in understanding how human groups create and conceptualize their cultural landscapes over time. Here I make an attempt to address these issues within this largely scaled sequence of cultural development in the region, but emphasize the necessity for more finely scaled cultural landscape studies in the future.

\section{Late Prehistoric Sites}

Prior to the Iron Age, the Prehistoric period sites seem to be concentrated in the mountain areas, especially in the Lan Saka district and the western districts of Nakhon Si Thammarat Province (Noonsuk 1997:129-133). Some Neolithic sites are on coastal land, including Khlong Klai and nearby Ban Bang Phan Sai; Ban Changhun in the south is also on an ancient beach ridge (Fig. 4). Polished hand axes and pottery sherds were found at these sites. At Ban Changhun, a burial with remains of a human skeleton and associated pottery sherds was found by villagers; this is the only prehistoric human skeleton found in coastal Nakhon Si Thammarat (Noonsuk 2013a:67). These Neolithic sites on beach ridges reveal early evidence of fishing communities in the area that were the forerunners of coastal communities in the Iron Age. 


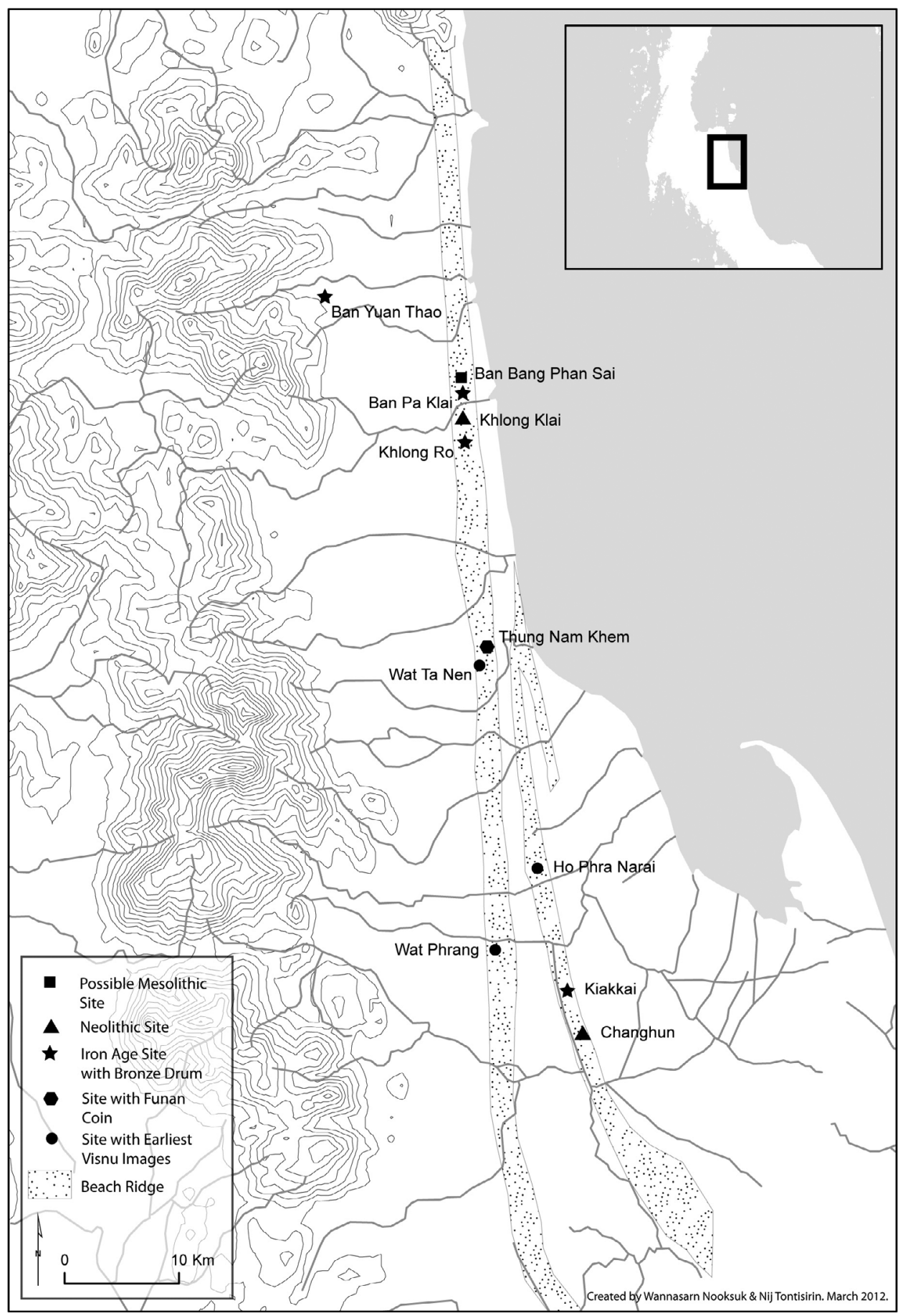

Fig. 4. Prehistoric and other related sites in coastal Nakhon. 
Table i. Iron Age Sites in Nakhon Si Thammarat

\begin{tabular}{llll}
\hline SITE NAME & OBJECT & NO. & \multicolumn{1}{c}{ DATE } \\
\hline Ban Yuan Thao & bronze drum & 1 & c. 5th-1st centuries B.C. \\
Khlong Ro & bronze drum & 1 & c. 5th-1st centuries B.C. \\
Ban Pa Klai & bronze drum & 1 & c. 5th-1st centuries B.C. \\
Kiakkai & bronze drum & 1 & c. 5th-1st centuries B.C. \\
Khlong Kut Duan & bronze drum & 1 & c. 5th-1st centuries B.C. \\
Muang Rae Kao & Han mirror & 1 & c. 50 B.C.-A.D. 8 \\
\hline
\end{tabular}

Sources: FAD 2003:192-196, 200-211, 215-219; Noonsuk 1997 :153-161.

Evidence of Iron Age sites on coastal land suggests the expansion of human occupation in this area. Five Dong Son bronze drums were found at five sites in Nakhon Si Thammarat Province and recorded by the Fine Arts Department in Thailand (FAD 2003). As seen in Figure 4, four of them are on coastal land, including one on the western side of the Nakhon Si Thammarat mountain range that also yielded a Western Han dynasty bronze mirror (Table 1). This area therefore has the highest density of bronze drums in the whole Malay Peninsula, confirming the significance of coastal Nakhon Si Thammarat in the Iron Age exchange network.

It is important to note that the areas where the bronze drums were found, including the sites of Ban Yuan Thao, Khlong Ro (Fig. 5a), Ban Pa Klai, Kiakkai (Fig. 5b), and Khlong Kut Duan, all developed into significant areas in the early Tambralinga period. The site of Ban Yuan Thao was situated between the Tha Thon and Plian Rivers. A group of early historic communities, of which Khao Kha was the most important religious center, later developed on the Tha Thon River. Ban Yuan Thao is situated in the foothill area between the mountains and a low plain. Close to the river headwaters, it is a source of tin, which was one of the most valuable products in the maritime exchange of this region, perhaps as early as the Iron Age. Its value lay in the fact that it was the main ingredient for making bronze. Two important sources of tin near this site include Ban Wayo and Ban Ao Yang Daeng in the mountain area, both of which were exploited until recently. These tin sources must have been crucial to the development of human communities in the adjacent coastal plains where the rivers and walking trails connected them to the tin sources.

The sites of Khlong Ro and Ban Pa Klai were in the same area as the Neolithic sites of Khlong Klai and Ban Bang Phan Sai, and an early Tambralinga site at Ban Klai. This area on the western beach ridge stands out as an area of settlement concentration in the Prehistoric period. There are two Neolithic sites and two Iron Age sites with bronze drums. It must have been an important hub of population at that time, probably due to the massive river system of Klai that supplied them with fresh water, food, resources, and routes to the inland communities. The communities in this coastal area were, in practical terms, the link between the maritime world and the inland communities.

The site of Kiakkai is situated in the southern portion of the eastern beach ridge, around $4 \mathrm{~km}$ south of the city of Nakhon Si Thammarat. In the late 1960s, villagers found a bronze drum, beads, gold items, iron tools, and pottery sherds here. I excavated two trenches at this site in 2009, and discovered glass beads (Fig. 6), iron tools, pottery sherds, and Chinese ceramics (Noonsuk 2013a:71-74). Although it has yet to 


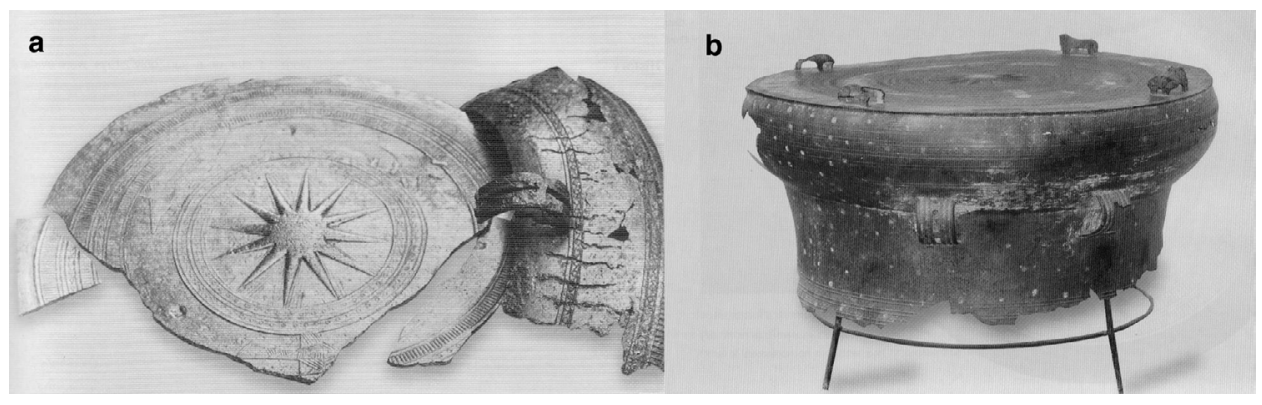

Fig. 5. Bronze drums found at peninsular Siam sites: a. from Khlong Ro or Sra Kaeo (FAD 2003: 200); b. from Kiakkai (FAD 2003:192), Nakhon Si Thammarat. (Photographs courtesy of the Fine Arts Department.)

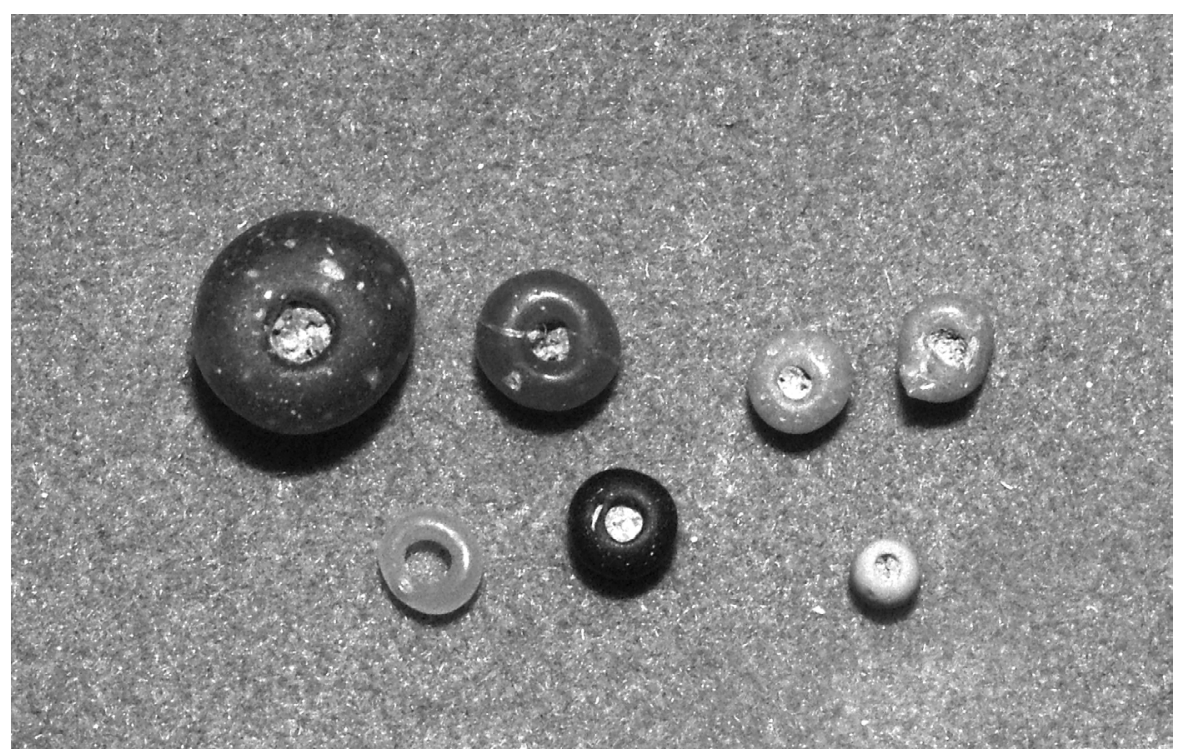

Fig. 6. Glass beads from Trenches KK.09.1 and KK.09.2, Kiakkai Site, Nakhon Si Thammarat.

yield any organic materials for radiocarbon dates, it may be preliminarily assumed that this area was inhabited by people since the Iron Age and continued to be an important area in the maritime trade until the thirteenth century.

The majority of the Dong Son bronze drums were found on the beach ridges, the geographical feature where all the Neolithic sites discovered so far in the coastal lands of Nakhon Si Thammarat have been found. It is clear that Prehistoric period people in this area oriented their vision to a broad seascape that united countless communities together and allowed materials, resources, and ideas to be circulated across a great distance. It is likely that there were already complex, stratified societies here and that iron, water buffalo, and diked paddy fields were a familiar sight to the peoples of this period (O'Connor 1986a:3). Wealth from surplus production, and trading of minerals and other products, may have been available to acquire exotic goods. 
Table 2. Results of Excavation in Trench KK.o9. I, Kiakkai Site, Nakhon Si Thammarat

\begin{tabular}{lccc}
\hline LOT & $\begin{array}{c}\text { DEPTH (CM } \\
\text { FROM SURFACE) }\end{array}$ & BASKET & NOTES \\
\hline 1 & 1 & $\begin{array}{l}\text { Blackish soil layer, containing a celadon sherd of the } \\
\text { Chinese Southern Sung-Yuan Dynasties and a } \\
\text { number of earthenware sherds }\end{array}$ \\
3 & $50-90$ & 2,3 & $\begin{array}{l}\text { Brownish soil layer, yielding two iron tools, a number } \\
\text { of small sherds, and three glass beads* } \\
\text { Reddish brown soil layer, with a few sherds } \\
\text { Yellowish soil layer with a few sherds found in the } \\
\text { very top part of the layer, but none below, } \\
\text { seemingly representing a largely sterile layer }\end{array}$ \\
\hline
\end{tabular}

*Beads pictured in Figure 6 above.

Table 3. Results of Excavation in Trench KK.09.2, Kiakkai Site, Nakhon Si Thammarat

\begin{tabular}{lccl}
\hline LOT & $\begin{array}{c}\text { DEPTH (CSM } \\
\text { FROM SURFACE) }\end{array}$ & BASKET & \multicolumn{1}{c}{ NOTES } \\
\hline 1 & $0-20$ & 1 & $\begin{array}{l}\text { Blackish soil layer containing a number of earthenware sherds } \\
\text { Brownish soil layer containing a number of earthenware } \\
\text { sherds and two glass beads* }\end{array}$ \\
3 & $20-70$ & 2,3 & $\begin{array}{l}\text { Reddish brown soil layer, with few earthenware sherds } \\
4\end{array}$ \\
4 & $70-120$ & 4 & Yellowish soil layer, culturally sterile \\
\hline
\end{tabular}

* Beads pictured in Figure 6 above.

\section{The Early Tambralinga Period, Visnu Images, and Hindu Shrines}

Communities on the coast of Nakhon Si Thammarat dominated maritime exchange during the Iron Age and into the early Tambralinga period. The communities on the beach ridges expanded toward the seashore, coastal plains, and foothill areas. Nothing demonstrates the significance of maritime contact in this coastal land in the early Tambralinga period more persuasively than the massive number of early Visnu images. Not only has coastal Nakhon Si Thammarat presented the highest density of the Dong Son bronze drums in the Malay Peninsula, it has also yielded the highest density of Visnu images of the earliest type in the whole of Southeast Asia. Thoroughly studied by Stanley J. O'Connor, they are called the "conch-on-hip" type (1965:59-97; 1972) (Fig. 7). These Visnu images are small (a bit more than half a meter), with tall, decorated miters; each Visnu figure holds a conch shell on his hip. Some images depict four-armed figures of Visnu in the sthanaka-murti or standing pose. They are usually shown wearing dhoti with their torsos nude and a broad sash falling in a semicircular arc in front of their thighs. These statues seem to be frontal, with only a few details on the back. They have three supports: the mass of cloth, a club (gada), and the main block of stone in which the legs and the heavy vertical fold of the dhoti between them are carved (O'Connor 1972:21). They were found at Chaiya in the Bay of Bandon and coastal Nakhon Si Thammarat. The one from Chaiya was originally found at Wat Sala Thung (Fig. 7a). The two images from Nakhon Si Thammarat were found at Ho Phra Narai (Narayana Shrine) (Fig. 7b) and Wat Phrang (now kept at Wat Mahathat) 


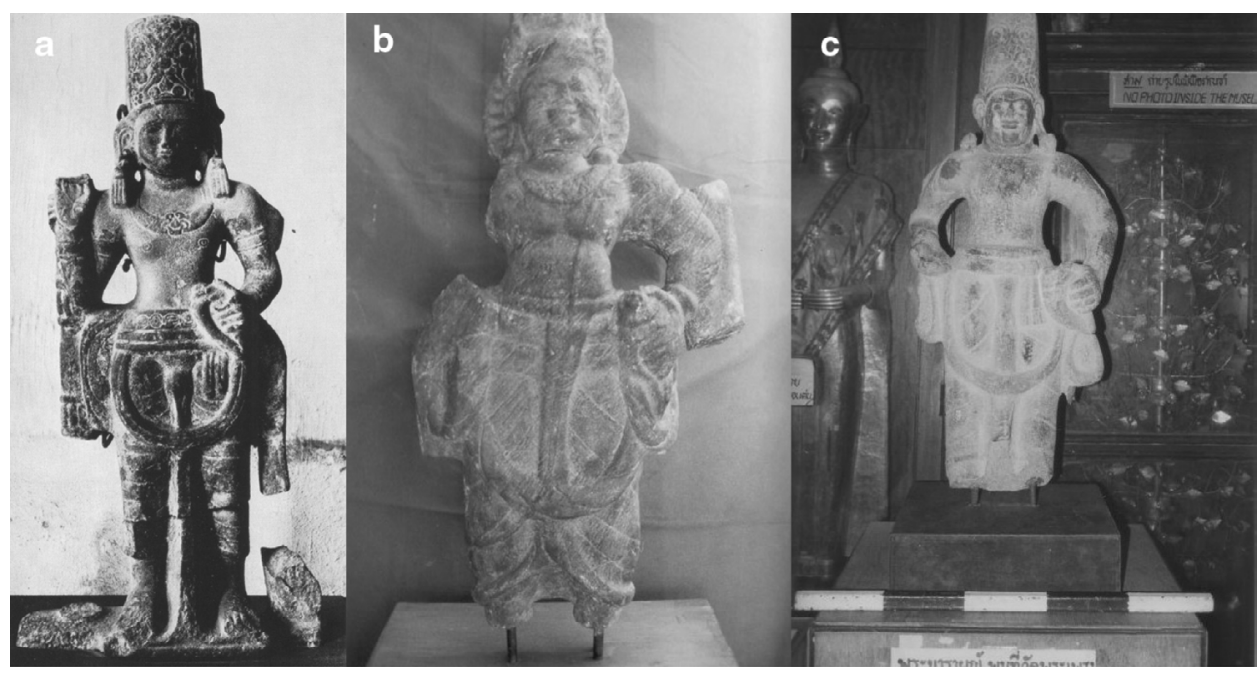

Fig. 7. Visnu images from peninsular Siam sites: a. from Chaiya (photograph courtesy of Stanley O’Connor); b. from Ho Phra Narai, Nakhon Si Thammarat; c. from Wat Phrang, Nakhon Si Thammarat.

(Fig. 7c). In 2002, another Visnu image of this style was discovered and published by me and my father, Preecha Noonsuk (Fig. 8). It was found at the site of Wat Ta Nen near Mokhalan in the Tha Sala district, which is also on the coastal land of Nakhon Si Thammarat (Noonsuk and Noonsuk 2003). Moreover, in May 2013, I discovered that there was an unpublished early Visnu head kept in storage at the Nakhon Si Thammarat National Museum (Fig. 9). This stone head was given to the Bangkok National Museum in 1949, but there was no record of its provenance. Based on documents or information that are no longer available to us today, high-ranking officials at the National Museum apparently believed that it was from peninsular Siam and therefore sent it to the Nakhon Si Thammarat National Museum when it opened in 1971. This head is exceptionally similar in style and size to the Visnu image from Chaiya (Fig. 7a) and may be dated to the same period, which would make this statue one of the two earliest Visnu images in Southeast Asia.

O'Connor (1972) established that the conch-on-hip images constitute the earliest group of Visnu images in Southeast Asia, emerging not long after their Indian prototypes from the early centuries A.D. Their style can be traced back to ultimate prototypes from the period of Kusana rule at Mathura (first to mid-third centuries A.D.), although the most immediate stylistic influence seems to be from the fourth-century art of the Andhradesa on the Coromandel coast of India. In the iconography developed at Mathura, the earliest images of four-armed Visnu have the anterior right arm raised with the hand in the abhayamudra gesture (i.e., palm open to the front). Visnu was depicted holding the padma (lotus) in his hand later, after the padma became a distinctive symbol. Since Visnu is shown raising his hand in abhayamudra, the Chaiya statue must have been produced earlier than those at Nakhon Si Thammarat that show him holding the padma blossom. O'Connor (1972:39) therefore dated the Chaiya statue (Fig. 7a) to no later than A.D. 400, while those at Nakhon Si Thammarat were 


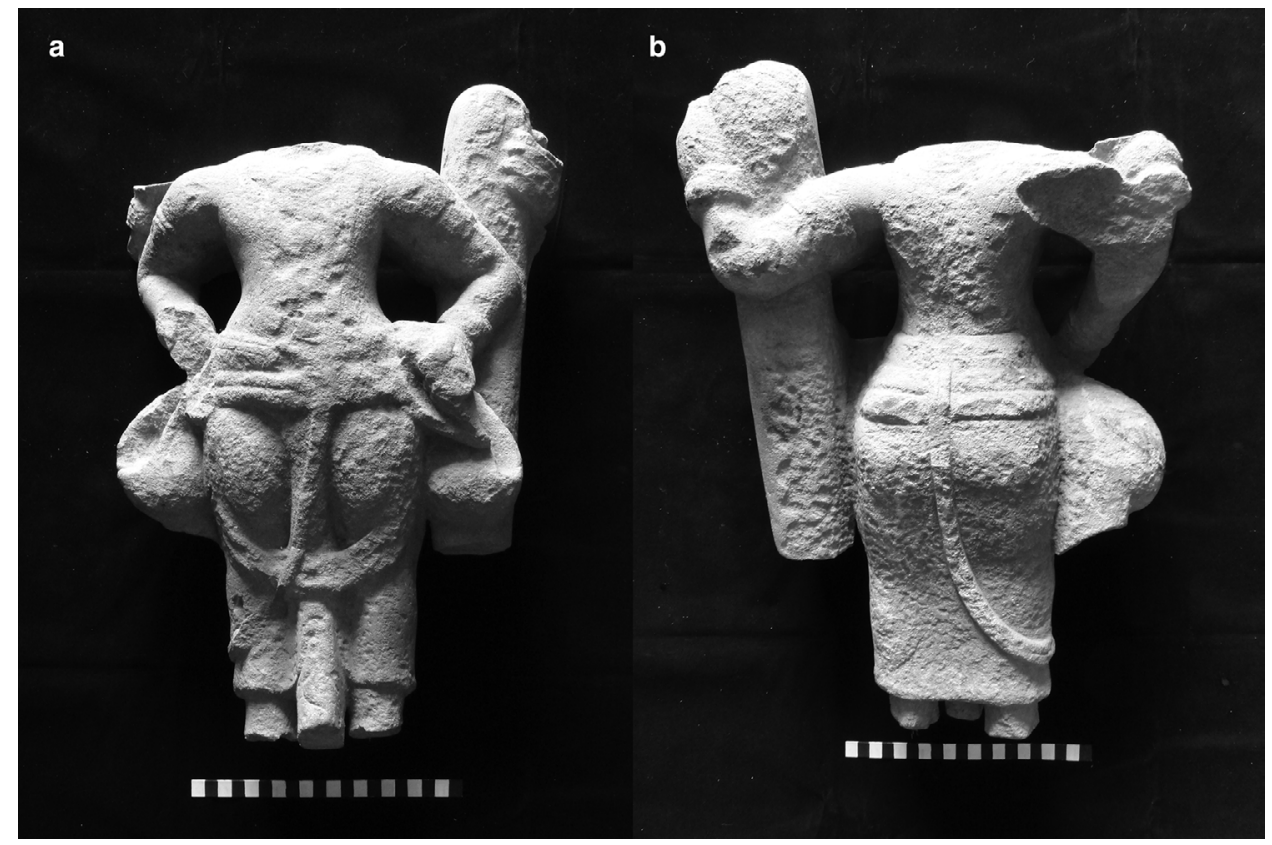

Fig. 8. Visnu image from Wat Ta Nen, Nakhon Si Thammarat: a. front of image; b. back of image.

dated to the fifth century A.D. However, Lavy $(2014: 169)$ recently argued that the Chaiya statue should instead be dated to c. A.D. 500, and those at Nakhon Si Thammarat (including the one from Wat Ta Nen) should be dated to the early to mid-sixth century A.D. Although there are two more images of this group from the Mekong Delta, the corpus of early Visnu images on the east coast of peninsular Siam is the earliest among them. It is now widely accepted that these isthmian images were the prototype of other Visnu images of the same style in Southeast Asia (Dalsheimer and Manguin 1998). This suggests that the isthmian tract, especially Tambralinga's heartland, was a significant center of innovation. It was also perhaps the center of a Vaisnavite (community of Visnu worshippers) commercial network in maritime Southeast Asia.

Two more unpublished Visnu stone statues were found near Nakhon Si Thammarat by members of the Fine Arts Department in the 1960s. ${ }^{2}$ The first was found in the Singkhon cave in the Khirirat Nikhom district, Surat Thani Province, northwest of Nakhon Si Thammarat; it was brought to the Nakhon Si Thammarat office of the Fine Arts Department in 1967. It is a small (48.5 cm in height), free-standing, fourarmed figure (most likely a Visnu image) made of limestone that is now very eroded (Fig. 10a). This statue is very crude. The buttressing structure, possible side shapes representing a sash, multiple arms, graceless contours, and flat graphic handling rather than fully realized volumetric forms all point to an early date, so early that there is little to compare it with in Southeast Asia (Noonsuk 2013a:78).

The second statue was found in 1962 in Wat Chiagphong in Ranot district, Songkhla Province, south of Nakhon Si Thammarat, and is now stored at the Nakhon 


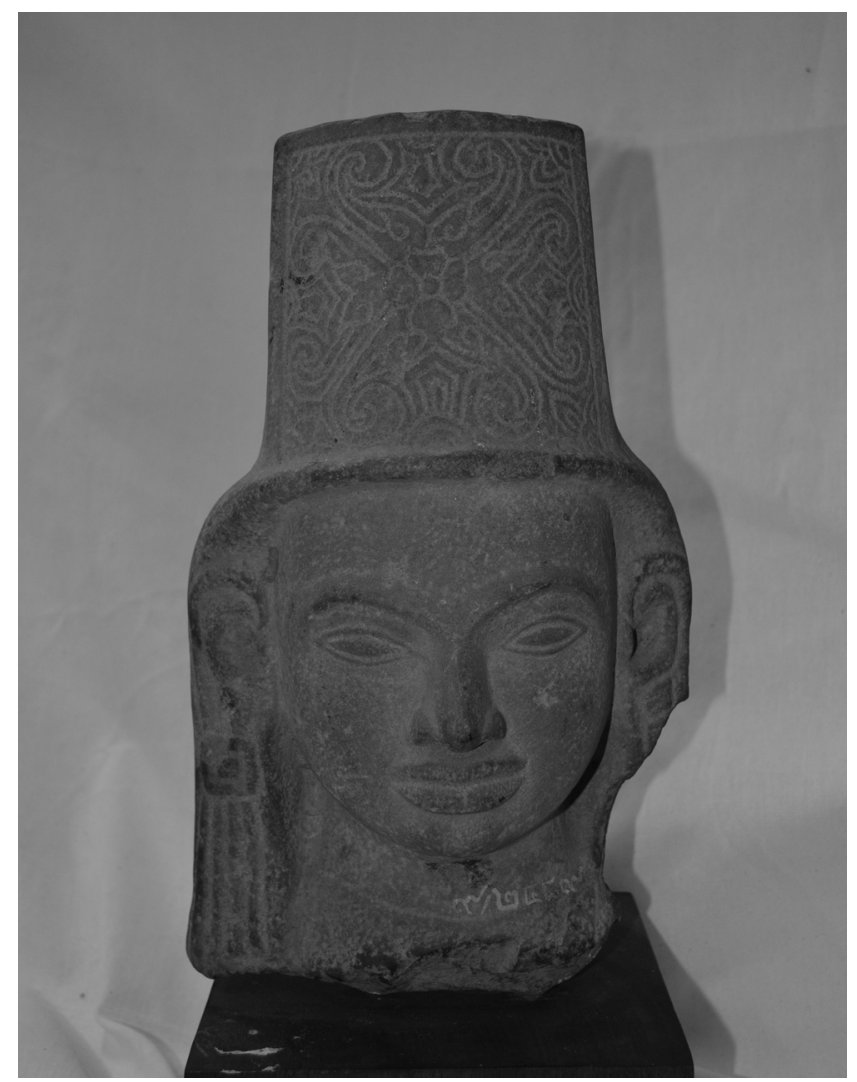

Fig. 9. Image of early Visnu head from peninsular Siam.

Si Thammarat National Museum. It depicts a standing Visnu with bare chest, four arms, and a miter (Fig. 10b). It is $31 \mathrm{~cm}$ in height, though broken from the thighs downward. The costume is a simple dhoti with no sash and scarf. It is totally threedimentional, although not very dynamic. These characteristics point to Dupont's group C, similar to the small Visnu image found at Wat Chom Thong, Sichon district, Nakhon Si Thammarat Province, which may be dated to the seventh century (JacqHergoualc'h 2002:123, fig. 12). However, the miter of this statue is decorated with floral patterns unlike that of the Chom Thong statue (Noonsuk 2013a:79).

It is important to note that the previously mentioned conch-on-hip Visnu images from Nakhon Si Thammarat were discovered on beach ridges that run in the northsouth direction at the edge of Tambralinga's heartland. The distribution of these images suggests that a common vision of Visnu worship spread along this strip of beach ridges in the fifth century, and that beach ridges were an important part of the settlement pattern of early historic communities in the heartland.

The number of archaeological sites in Tambralinga's heartland increased tremendously in the early Tambralinga period. Based on previous reports and my own surveys, I have been able to identify 89 brick shrines associated with Hinduism in this area (CMDNST 1985; Noonsuk 2004, 2013a). ${ }^{3}$ Almost all of the brick shrines in 


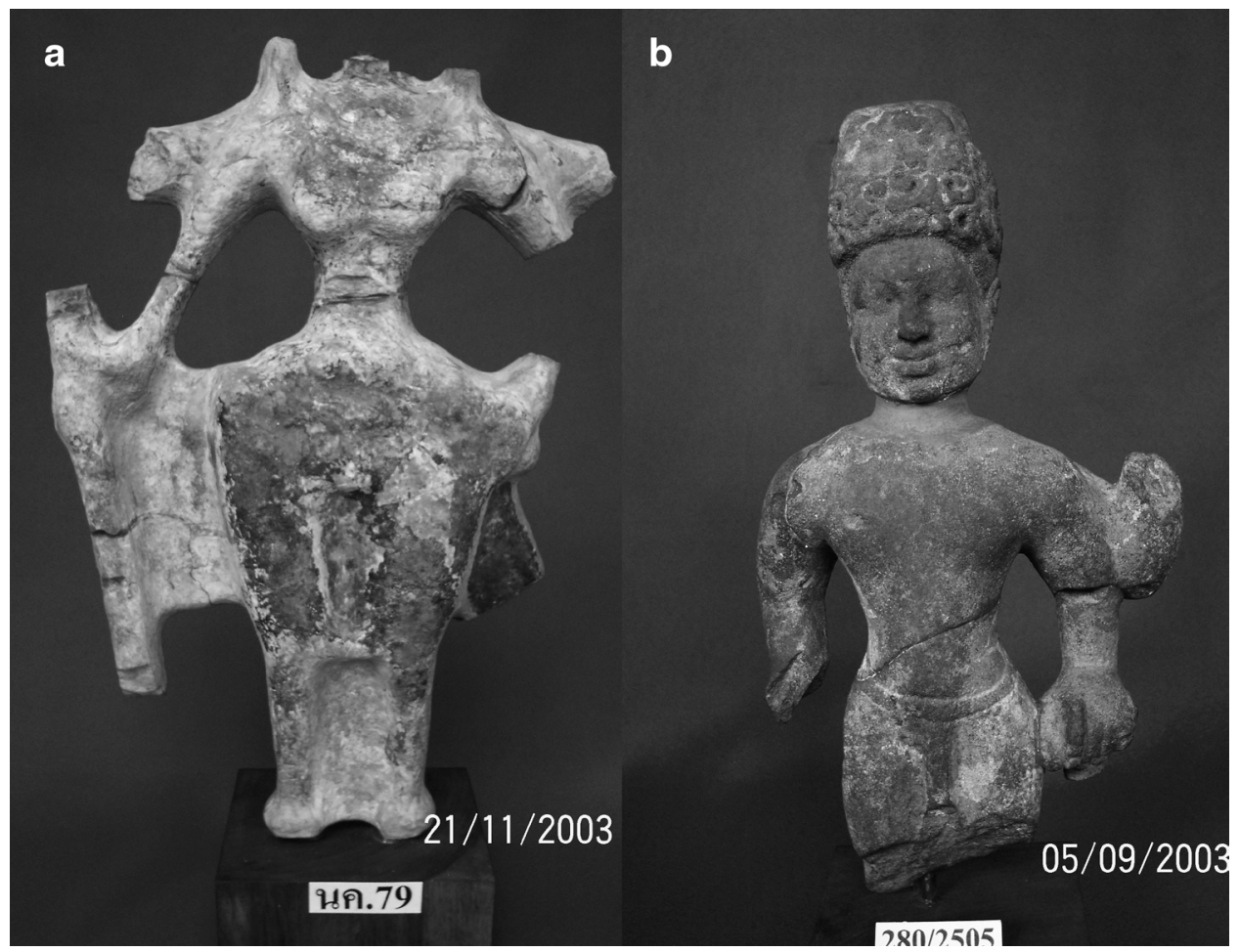

Fig. 10. a. Possible Visnu image from the Singkhon cave, Khirirat Nikhom district, Surat Thani Province; b. Visnu image from Wat Chiangphong in Ranot district, Songkhla Province.

Tambralinga's heartland were associated with Hindu sculptures, especially lingas (phallic symbols of Shiva) and yonis (vaginal symbols of Shiva's consort, usually at the base of lingas) and ablution basins for statues (Figs. 11-13). Although Buddhist sculptures have been discovered in this area and preserved in museums, their exact original locations have not usually been recorded. According to archaeological record, however, Hindu shrines were most prevalent in this area in the sixth to eleventh centuries. This suggests that Hinduism dominated the social life of the people in this area at that time (Noonsuk 2013b).

These shrines generally appear simple, small, and primitive. They seem to fall into the category of a "minimum program of temple construction" (Jacq-Hergoualc'h 2002:137-139) in which shrine architecture is kept to a minimum and focuses on a cella, a small room (even in a large temple) in which a representation of the god of the temple is installed and in front of which rituals and worship take place. These shrines usually had a brick foundation; they may have had a wooden superstructure and thatch roof, but these have perished. Almost all cella were accompanied by ponds, which usually can be identified today. Stone architectural parts such as thresholds, lintels, door frames, and moonstones were normally made of limestone, but some were granite and had decorative carvings (Figs. 14-15). According to my research, these stone architectural parts are characteristic of Hindu shrines, since they are not found in any contemporaneous Buddhist temples in the area (Noonsuk 2013a:103-109). 


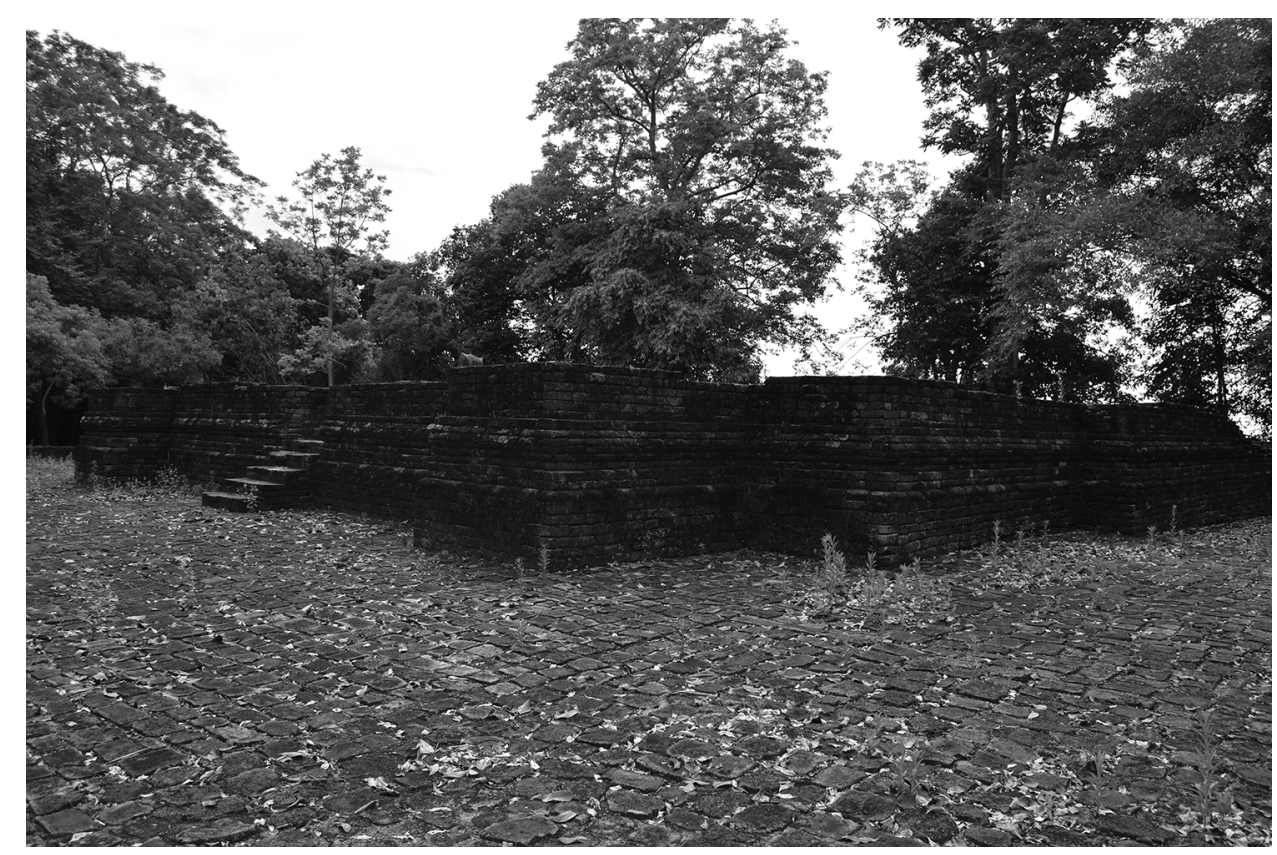

Fig. 11. Monument No. 2 at Khao Kha, Sichon district.

These shrines are tentatively dated to the sixth to eleventh centuries, based on the stylistically dated sculptures found in them.

Two shrines that I excavated in 2009 have acquired scientific dates using the thermoluminescence (TL) technique conducted by the TL lab at Kasetsart University in 2011. The first is the brick foundation at Wat Thao Khot in the city of Nakhon Si Thammarat (Fig. 16). Although the stone architectural parts were not discovered in the trench, they were still scattered around the site (Fig. 17). The foundation was found $160 \mathrm{~cm}$ below the surface. A brick sample from this foundation was dated to $1200 \pm 90$ B.P. or A.D. 721-901. The second is the brick foundation at Wat Phrang (Mound 1), where a fifth-century Visnu image was found nearby. Three floors have been identified by excavating the top of this mound (Fig. 18). The first two were brick floors, while the uppermost one was a dirt floor. I was only able to obtain two TL dates for brick fragments from the second floor in the middle: $1298 \pm 141$ B.P. and $1292 \pm 135$ B.P., or A.D. 572-854 and A.D. 584-854 respectively. These TL dates provide clues suggesting that some of these shrines were built in the late sixth to ninth centuries. More scientific dates from future research will offer a more precise chronology of these shrines.

Although these shrines are not direct evidence of residential areas, they suggest the existence of human communities. A shrine could not exist without human construction and support. Communities must have taken part in constructing and maintaining them as they were the sites of their faith. In some areas, Hindu shrines clustered intensely, indicating the existence of a large human settlement. However, some shrines were situated in isolated areas, suggesting the presence of isolated communities or that they were shrines used by passing travelers on routes of communication. In any 


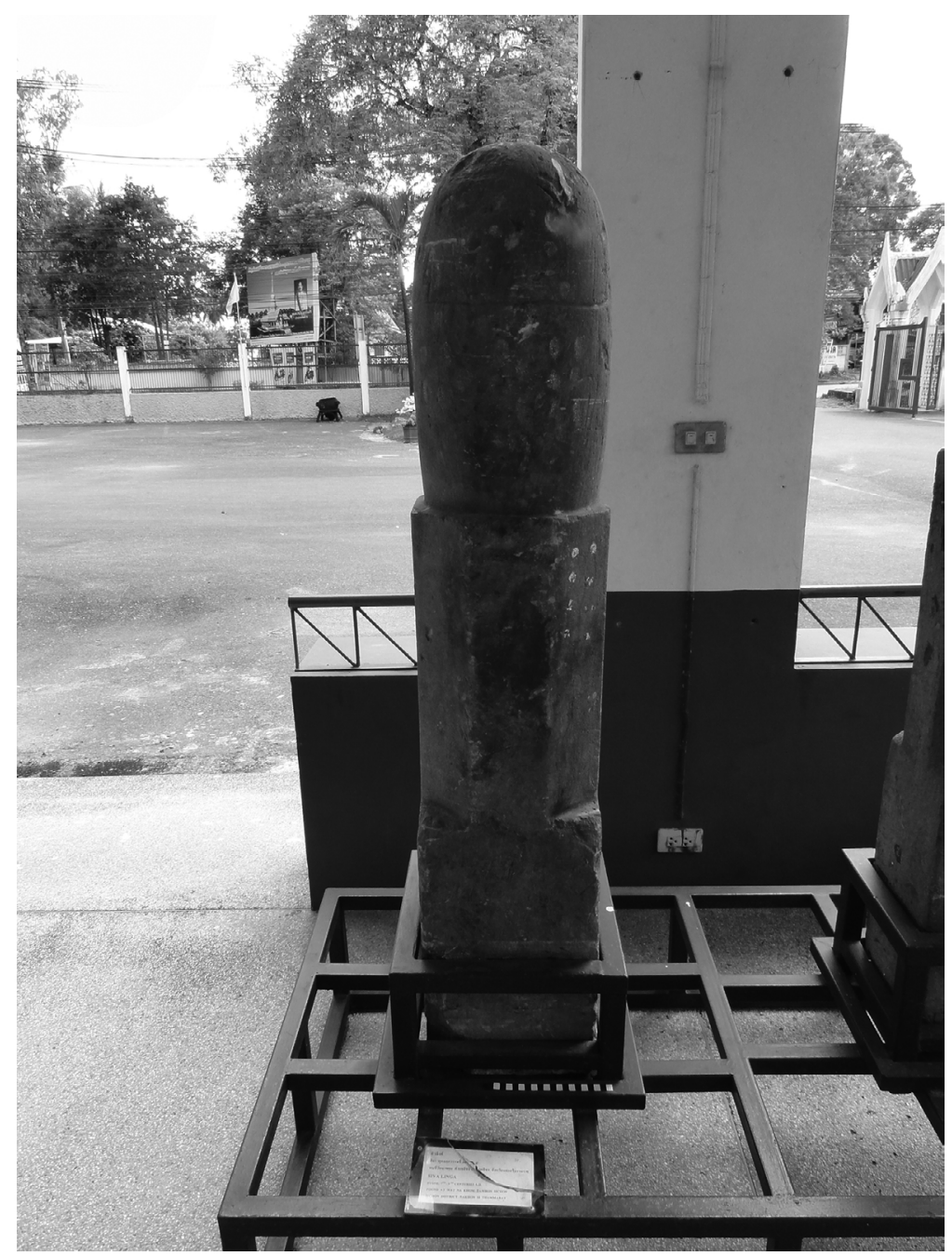

Fig. 12. Siva linga from Ban Na Khom, Sichon district.

case, any shrine must have been within reach of settled communities so people could come to worship and maintain it.

Ritual spaces that constituted the cultural landscape were not limited to brick shrines, however. A few years ago, villagers discovered four small gold lingas in a natural limestone cave in the Phli Mueang hill near the Phlai Dam Mountain, not far from where a seventh-century Visnu image was found in Wat Chom Thong at the northern end of Tambralinga's heartland. The Fine Arts Department acquired two of them in 2014; the other two were sold to private collectors. According to the villagers, the gold lingas were enclosed in several layers of containment and buried underground at different locations (although two were found together in one box). ${ }^{4}$ The outermost layer in each case was a small (around half a meter in diameter), square brick structure (Fig. 19). Each brick in the structure was around $30 \mathrm{~cm}$ long, $16 \mathrm{~cm}$ wide, and $9 \mathrm{~cm}$ thick. 


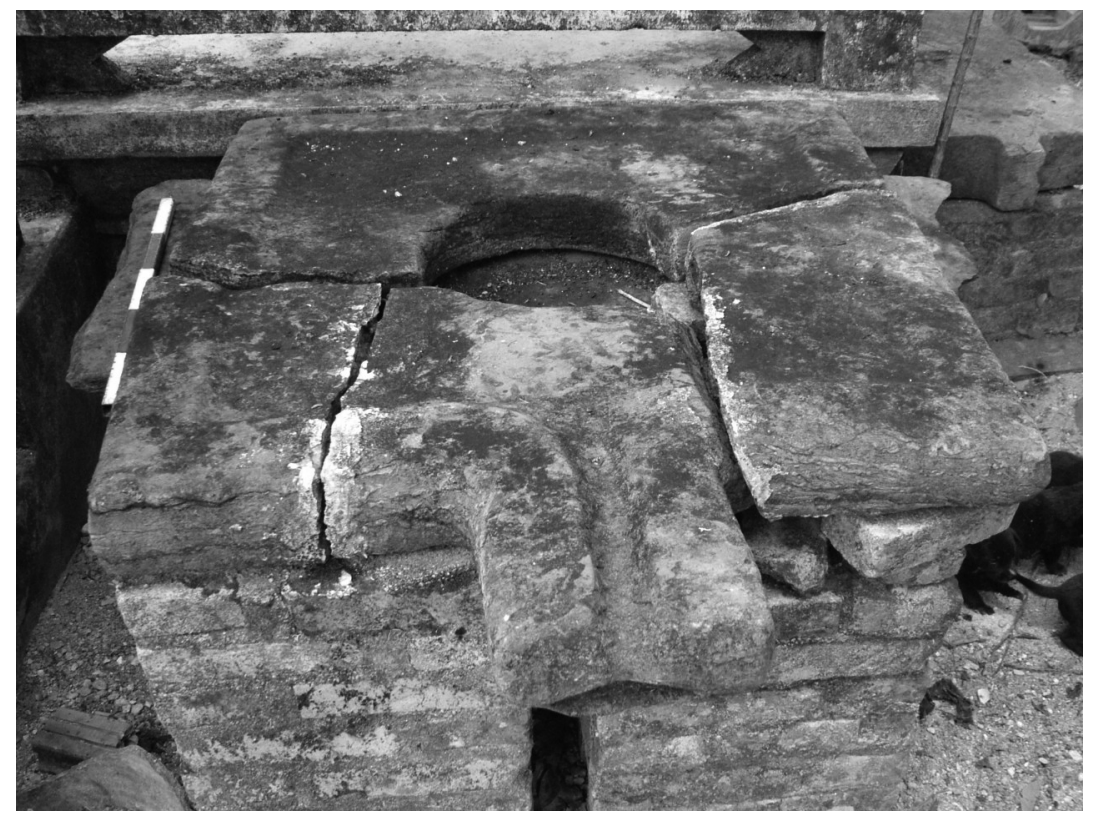

Fig. 13. Yoni from Wat Boek, Sichon district, Nakhon Si Thammarat.

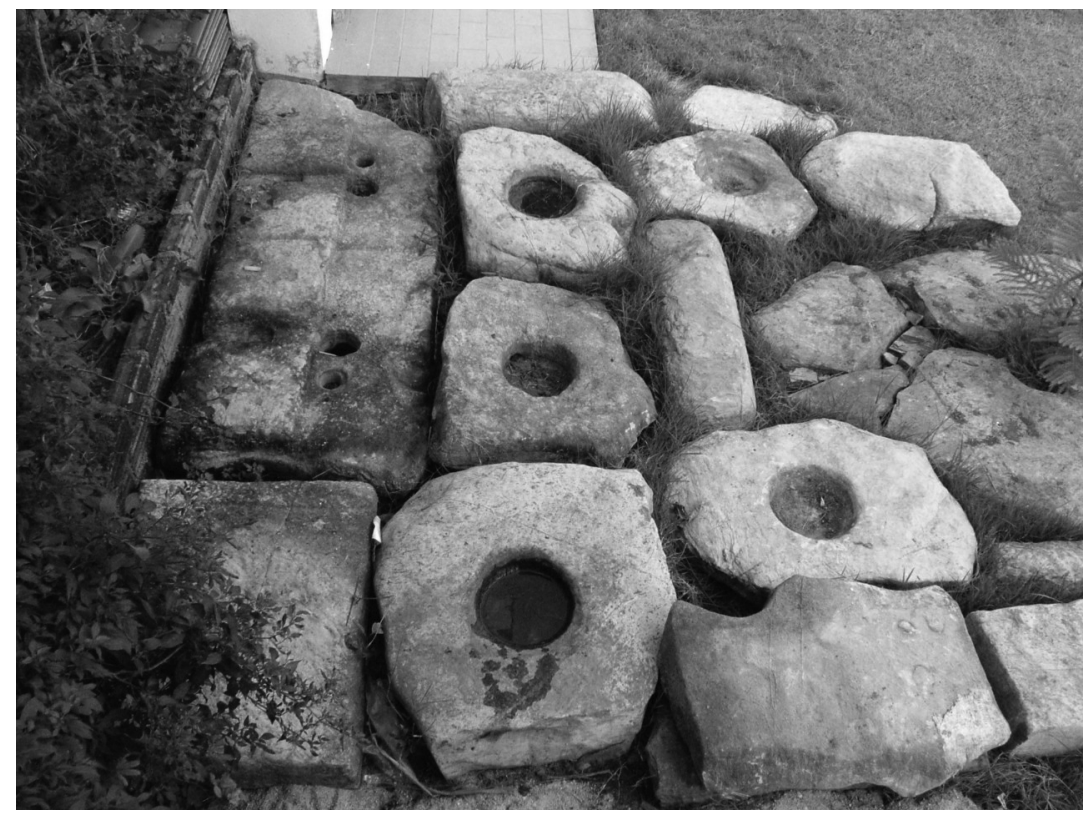

Fig. 14. Various architectural parts from Ban Hua Thon, Sichon district, Nakhon Si Thammarat. 


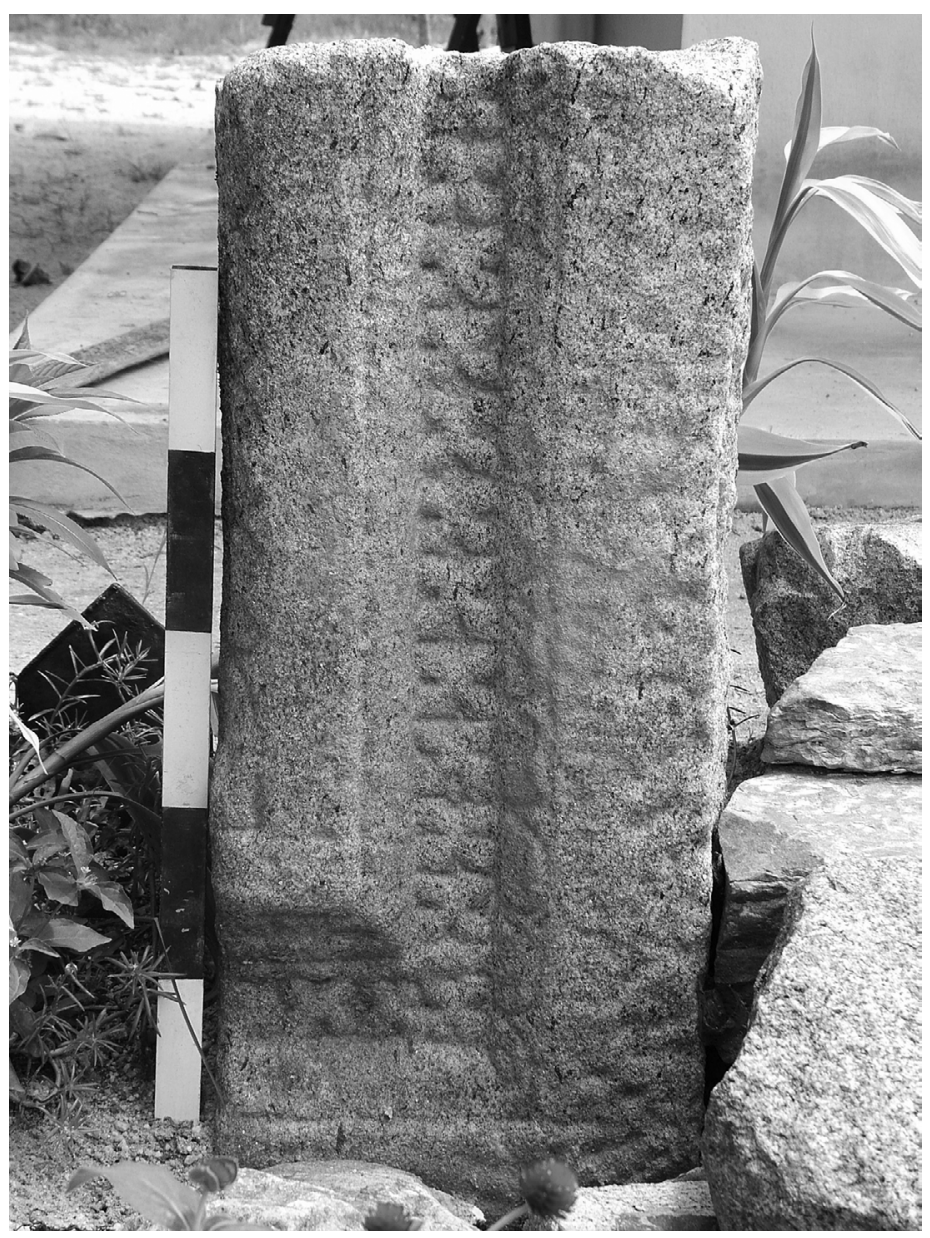

Fig. 15. Decorated granite door frame in Wat Phra Mongkut, Mueang district, Nakhon Si Thammarat.

Within each brick structure was either a round, stone, or square, terracotta hollow box made of two identical top and bottom halves that, put together, created the container (Fig. 20). Each half of the terracotta box is around $16 \times 16 \mathrm{~cm}$ and $7 \mathrm{~cm}$ thick; the hollow space inside is around $7 \times 7 \mathrm{~cm}$ and $3 \mathrm{~cm}$ deep (Fig. 20b). The two lingas acquired by the Fine Arts Department had been inserted into metal containers (possibly made of lead) of different shapes inside the boxes. These metal containers were the innermost layer of container or covering for the lingas. Three out of the four lingas have silver bases (Fig. 21a). Some have small pieces of gold foil inserted into holes in the bases as well; that is, there is gold foil between the lingas and their bases.

The lingas themselves seem to be identical (Fig. 21b). They are only $2 \mathrm{~cm}$ in height and $0.8 \mathrm{~cm}$ in diameter. Like common traditional lingas, they can be divided into three sections: the cylindrical Rudrabhaga, octagonal Visnubhaga, and square Brahmabhaga. However, the oversized Rudrabhaga is swollen in the topmost part, instead of being straight as in other lingas, and has been decorated with lines represent- 


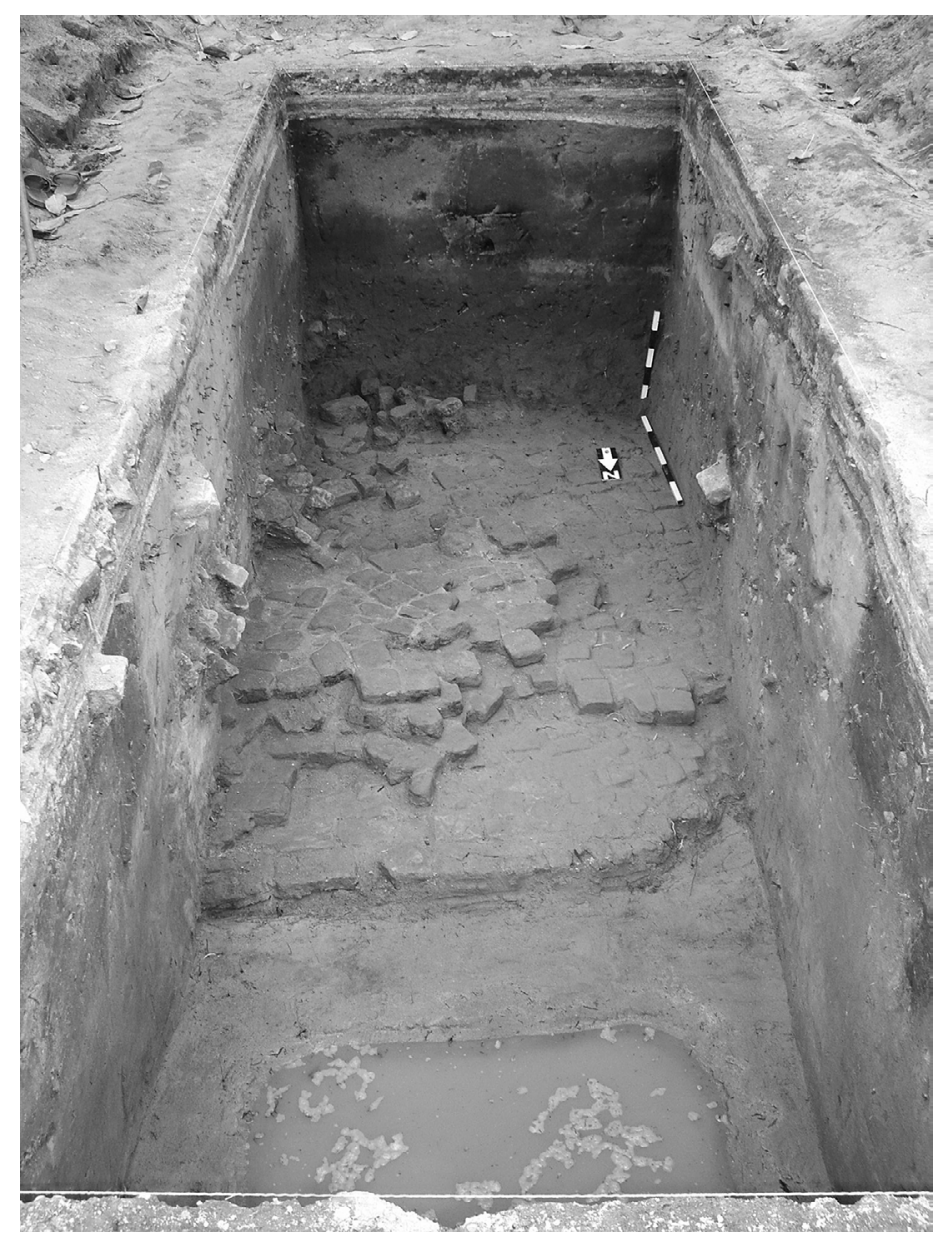

Fig. 16. Brick foundation at Wat Thao Khot (Trench TK.09.1), Mueang district, Nakhon Si Thammarat.

ing the glans and frenum. These characteristics point to an early date for these lingas, perhaps as early as the late fifth to early sixth centuries A.D. They are stylistically very similar to the early stone linga found at Yarang in Pattani Province, which JacqHergoualc'h (2002: fig. 82) dated to the sixth century A.D. The rare discovery of these gold lingas in their contexts reflects the sacredness of caves and mountains in the Hindu spiritual landscape of Tambralinga.

The distribution of Hindu shrines suggests that human communities were spread throughout all the ecological zones of coastal Nakhon Si Thammarat from the mountains to the seashores (Fig. 22). There appear to be at least five large-scale clusters based heavily along river systems. Some sites such as Sra Riang and Rong Lek are quite far away from other sites, however. They do not seem to belong to any cluster, which may suggest that they were supported by relatively isolated communities.

Some clusters are easier to identify than others. In some areas such as the plain between the Tha Chieo and Tha Thon Rivers (see Fig. 3), many sites are concentrated in a relatively small area (Fig. 22). This area undoubtedly represents a cluster of sites or 


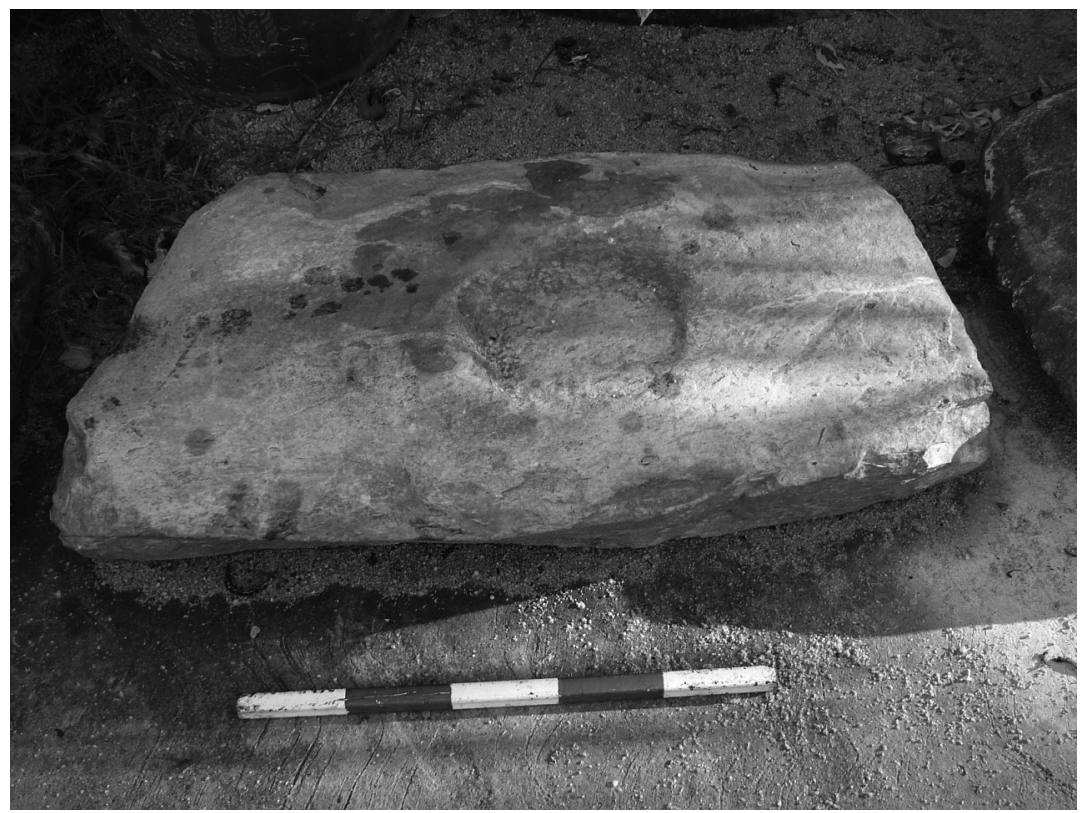

Fig. 17. Stone pillar base at Wat Thao Khot, Mueang district, Nakhon Si Thammarat.

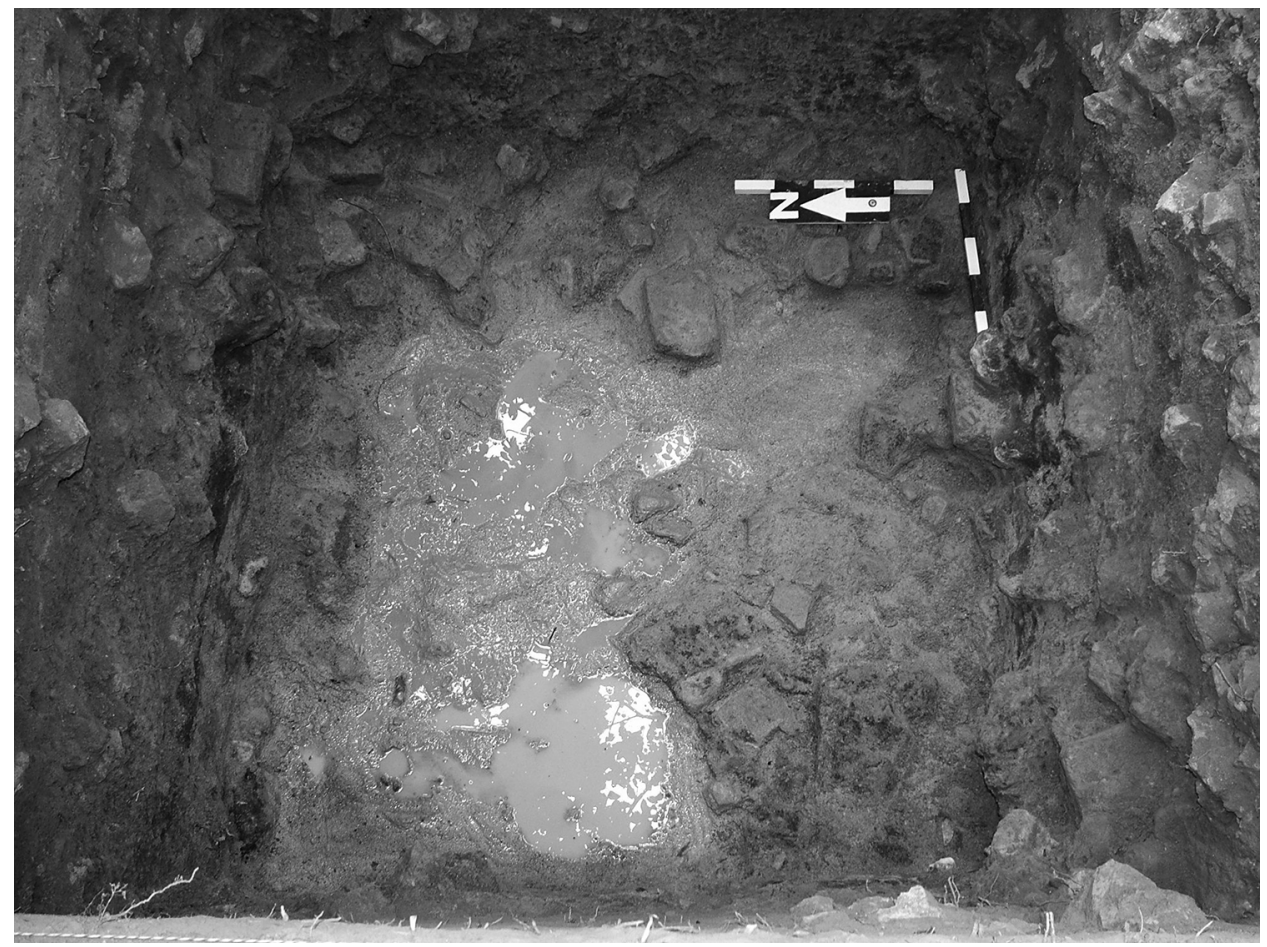

Fig. 18. Lowest brick floor at Wat Phrang (Trench WP.09.3), Phra Phrom district, Nakhon Si Thammarat. 


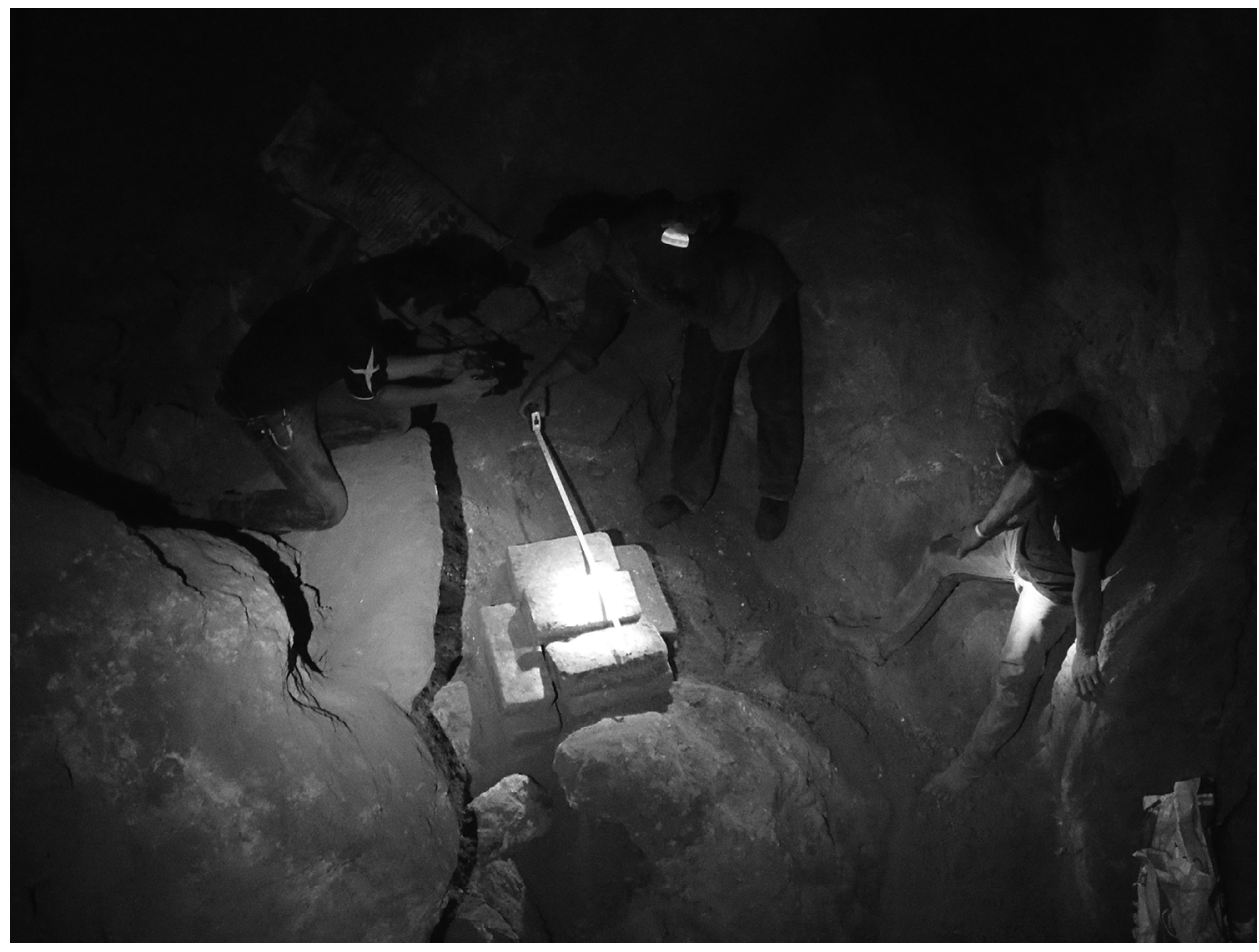

Fig. 19. One of the small brick structures surrounding the lingas in the cave in the Phli Mueang hill, Sichon district, Nakhon Si Thammarat. (Photo courtesy of Chutharat Chuachin.)

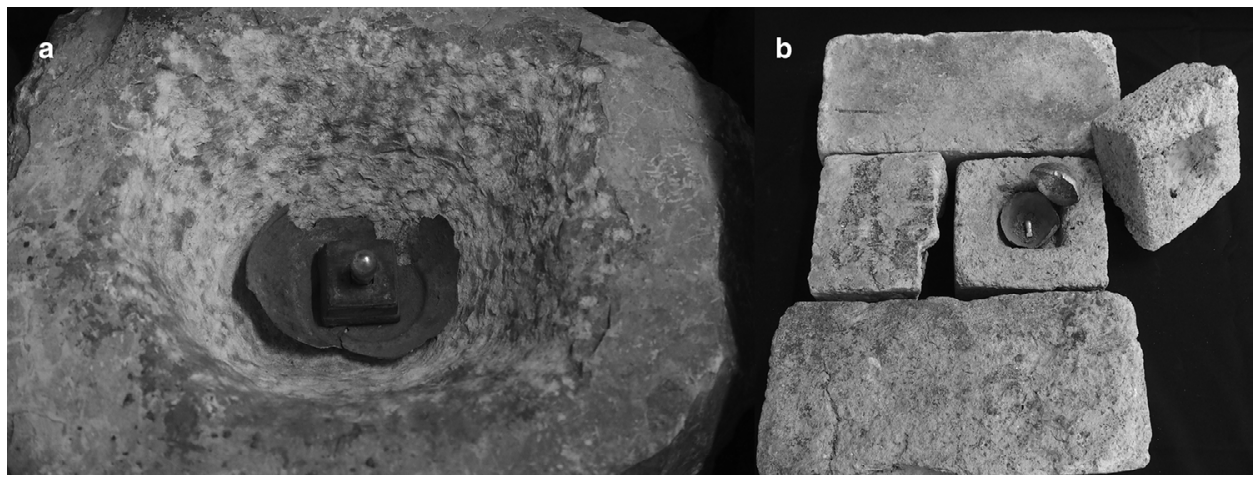

Fig. 20. a. The gold linga fixed on a silver base in a fragmented metal container and stone deposit box from the cave in the Phli Mueang hill, Sichon district, Nakhon Si Thammarat; b. gold linga inside metal container and terracotta deposit box and surrounded with bricks, from cave in Phli Mueang, Sichon district, Nakhon Si Thammarat. (Photographs courtesy of Chutharat Chuachin.) 


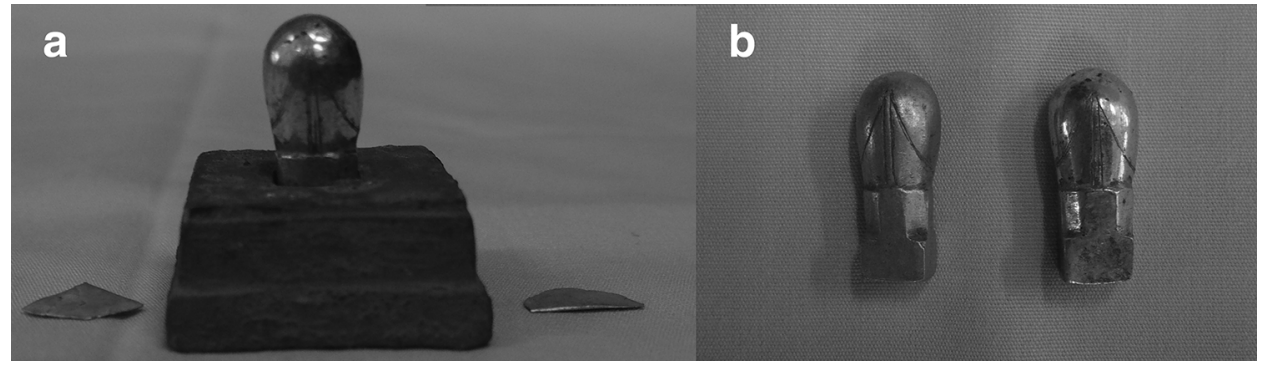

Fig. 21. Lingas from cave in Phli Mueang hill, Sichon district, Nakhon Si Thammarat: a. gold linga fixed on silver base, gold foil originally inserted between the linga and the base; b. two gold lingas acquired by the Fine Arts Department. (Photographs courtesy of Chutharat Chuachin.)

perhaps even an early city, which would in turn suggest that it stood in sociopolitical dominance over other areas. The site of Khao Kha seems to be the most prominent religious center of this cluster, perhaps in the whole heartland. It is a low-lying hill running almost north-south, with a number of brick shrines on its ridge. At the northern end of this hill is a monumental Siva linga carved from a natural outcrop and surrounded by a dirt platform with stone retaining walls (Fig. 23). Its location again reflects the power of distinctive, high places in the religious imagination of the ancient people in this area. Two brick samples acquired during survey in the unexcavated area on the ridge of the hill south of this linga were TL-dated in 2014 by the TL lab at Kasetsart University to $1536 \pm 123$ B.P. and $1562 \pm 109$ B.P., or A.D. 355-601 and A.D. 343-561, suggesting that the brick structure(s) on the hill may have been first constructed at a very early time.

Mapping these clusters represents only one of the ways this author has attempted to understand the distribution of sites in a large-scale analysis. The clusters may or may not represent a past reality. It is never accurate to draw a simple boundary between sites and rivers that spread organically throughout the landscape. There also must have been smaller groups of communities existing within these clusters that we are not able to detect at this time. Furthermore, any site could have relationships in all directions. It is also important to note that the sites discussed in this work are only the ones for which we have exact locations. It can be expected that the number of early Tambralinga period sites known will increase with future research.

\section{Cultural Geography}

Looking from the sea to the heartland of Tambralinga, the prominent body of the Nakhon Si Thammarat mountain range is like a massive curtain behind the flat stage of the coastal plains where most of the activities of the kingdom took place. When viewed from the sky, this mountain range is the ultimate source of countless rivers flowing through the coastal plains to the sea. The mountain range, the coastal plains, and the rivers all seem to take part in the geographical unification of the heartland; however, nothing is more prominent in this regard than the beach ridges that cut across all the clusters of communities from the northern to the southern ends of the heartland. It could be argued that Tambralinga was essentially a beach ridge society, in that the beach ridge was the core of its landscape and routes of communication (Fig. 4). 


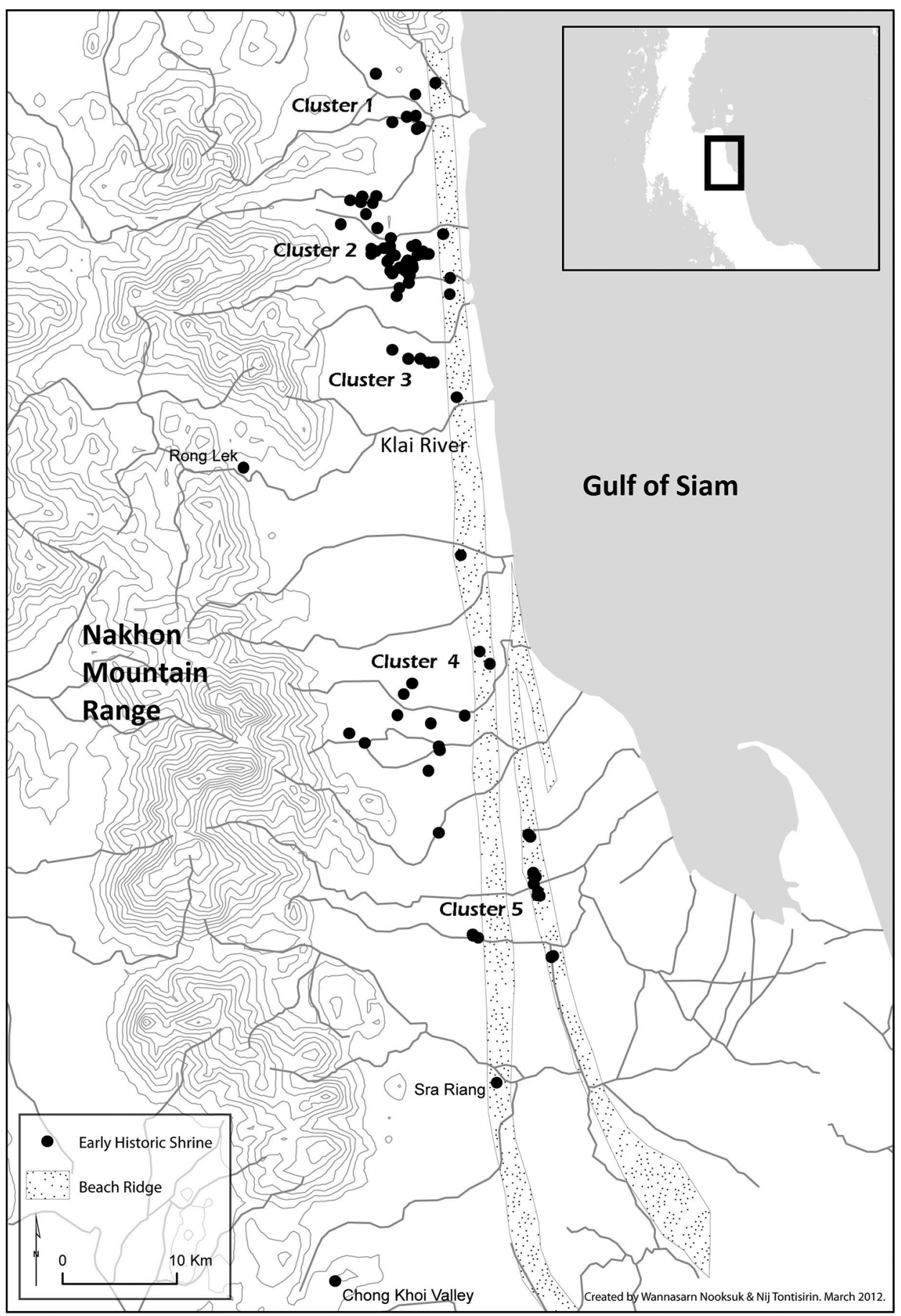

Fig. 22. Distribution of Hindu shrines in the early Tambralinga period (c. fifth to eleventh centuries). 


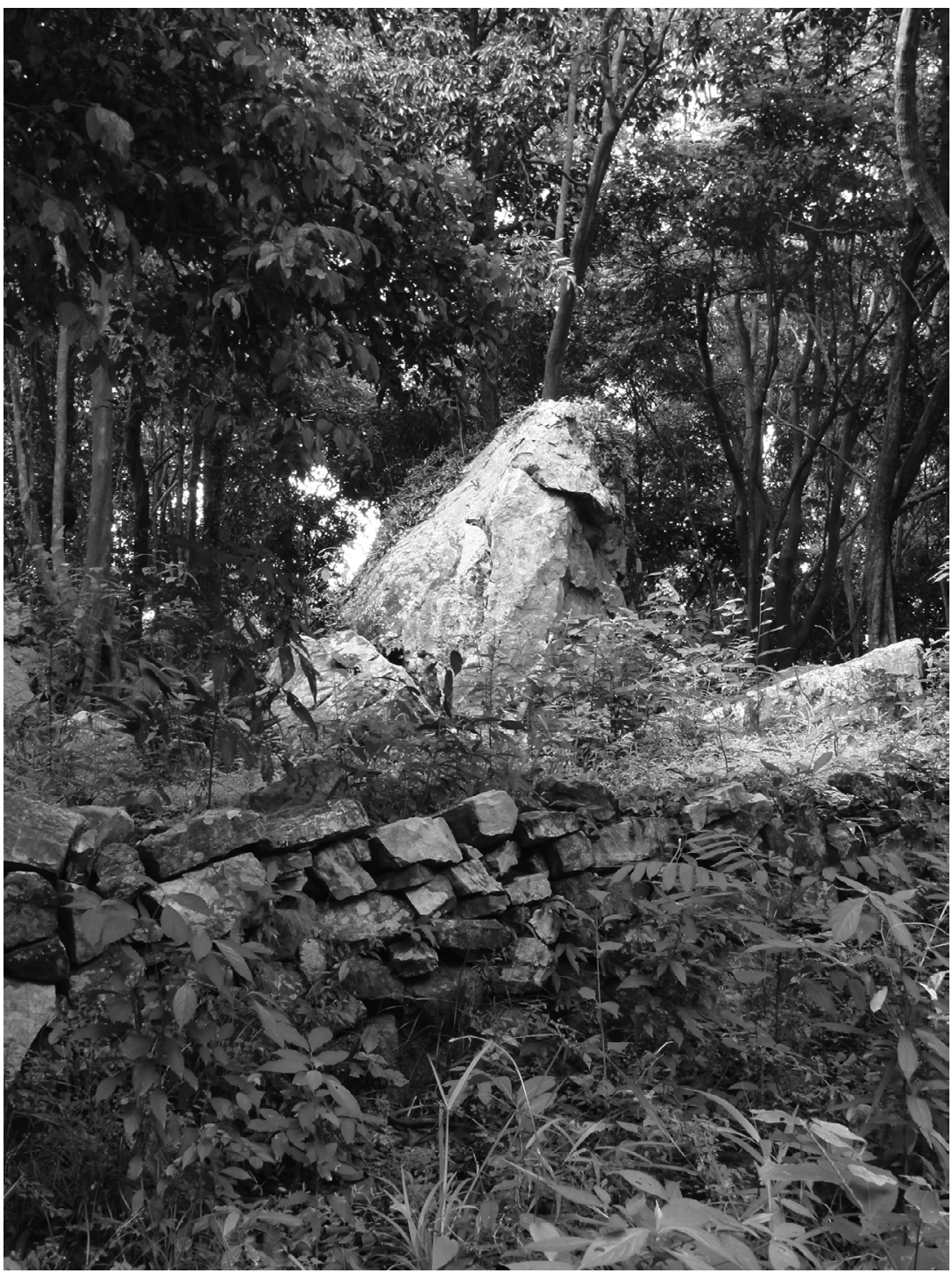

Fig. 23. Northern Svayambhuva-linga at Khao Kha, Sichon district, Nakhon Si Thammarat.

Beach ridge societies are different from riverine societies (e.g., Chao Phraya, Lower Mekong basin) where large rivers dominate the landscape. Clusters of communities in these areas grew up around rivers and used them to communicate with other clusters. The rivers cut across the landscape and linked the clusters together. In the Angkor Borei area, close to the Mekong Delta, people dug canals instead of building roads to facilitate communication and transportation of goods and people between communities that were like islands floating on the marshes of rice fields. ${ }^{5}$ One canal bed is dated by optically stimulated luminescence (OSL) and radiocarbon dating to between the first millennium B.C. and the middle of the first millennium A.D. (Bishop et al. 
$2003: 319)$. The people in this area seem to have created the most extensive canal network in Southeast Asia.

River routes were crucial in transportation and communication. However, on a large scale, the rivers could not provide channels of communication between communities because the rivers were too short and ran mainly east to west. There were no riverine links between communities that were situated far away from one another on the north-south axis (Fig. 3). Beach ridge societies such as those commonly found on the east coast of peninsular Siam around the Bay of Pattani, Sating Phra, and coastal Nakhon Si Thammarat did not build canals. Instead, they used the beach ridges as highways of communication. The beach ridge of coastal Nakhon Si Thammarat was the only geographical feature on which people could actually walk or on which ox carts could travel from north to south through the heartland. According to old villagers in Nakhon Si Thammarat, the beach ridge was in continuous use as a walking route until recently, when the government decided to build a superhighway on top of it. As a superhighway, it still maintains its significance as the core of transportation in Nakhon Si Thammarat Province.

The beach ridges were the core of Tambralinga's heartland, but they were not the only ecological zone in the area. Communities in the heartland spread out to occupy diverse ecological niches from the shores to the mountains. This ecological diversification may have been the strength of Tambralinga (just as it is today) in that its communities were able to support and complement one another in terms of access to resources and different geographical advantages. Three large-scale ecological zones in the heartland from east to west include the seashores, floodplains, and mountains. The seashores, including the beach ridges and estuaries, have been an important area of human habitation since at least the Neolithic period; indeed, three bronze drums have been found in this area. Even today, the communities in this area are involved with fishing and maritime trading. They provide important marine and coastal products such as shrimp paste, dried fish, and salt to inland communities.

Suitable for rice cultivation, the floodplains behind the western beach ridge was formed mainly by alluvial deposits. This ecozone was extensively inhabited by people in the early Tambralinga period (c. fifth to eleventh centuries). Only one site in this area has been identified as an Iron Age site, but there were more than 70 sites here in the early Tambralinga period. The enormous increase in sites suggests that the population expanded into the floodplains, probably to grow rice. During the rainy season today, the communities in this area are practically floating on rice fields. These communities are the main providers of rice and cattle for communities in other ecozones.

The foothill and mountain areas seem to have been sparsely populated; very few sites dating from the Iron Age or early Tambralinga period have been found here. However, they were the source of forest products and minerals, especially tin, that were valued highly by foreign merchants. Until recently, these products were collected by villagers and sought after by both local and foreign traders. People in the heartland could connect to areas on the west coast of the isthmian tract via mountain passes.

Until a few decades ago, villagers relied on rivers and foot trails to distribute resources and products from their own into other ecozones. A sense of neighborliness and complementarity in the economic exchanges was likely strong. The economic relationship could be described as based on trust, in that there were no fixed prices for 
goods in the transactions. The cattle from the rice plains could be left safely with acquaintances in the foothills during the rainy season. The flow of daily life established social connections between the people in the seashores and the mountains.

\section{CONCLUSION}

Geography played a vital role in the social development of Tambralinga. Tambralinga's unique location and geography opened it to maritime trade and cultural influences that allowed cosmopolitanism and civilization to emerge. Tambralinga's heartland looked out on the South China Sea, with the mountains in its metaphorical backyard. As the source of exotic goods such as forest products and tin that were valued very highly by foreign merchants, the mountains were important to the kingdom's trade and development. Situated between the shores and the mountains was a floodplain that produced rice and cattle for the population in the kingdom. The beach ridges formed the core of the kingdom's landscape. They were used as the main communication route that connected various communities together in the north-south direction, while rivers and walking trails provided passageways between ecological zones in the east-west direction. Tambralinga's heartland also connected to the west coast of the isthmus via transisthmian routes across the mountain passes and plains.

This area has yielded the highest density of bronze drums (c. late centuries B.C.) in the Malay Peninsula and early "conch-on-the-hip" Visnu images (c. fifth century A.D.) in Southeast Asia. Tambralinga seems to have served as the center of innovation of Visnu images in the region. Its heartland also has the highest density of early Hindu shrines and stone inscriptions (c. fifth to eleventh centuries) in the isthmian tract. It can be seen that the significance of Tambralinga as a cultural center was closely linked to its landscape.

\section{ACKNOWLEDGMENTS}

In completing this article, I am indebted to many generous people and organizations, all of whom I may not be able to mention here. First, I would like to express my deepest gratitude to His Majesty King Bhumibol Adulyadej of the Kingdom of Thailand and Her Royal Highness Princess Maha Chakri Sirindhorn for supporting my graduate studies in archaeology during 2002-2012. I am grateful to many of my professors, including, but not limited to, Stanley J. O'Connor, Kaja McGowan, Andrew Ramage, Magnus Fiskesjö, P.-Y. Manguin, Miriam Stark, James Bayman, Michael Aung-Thwin, Leonard Andaya, Dhida Saraya, Mayuree Veeraprasert, Maneepin Phromsuthirak, and Somsuda Leeyawanich. I am indebted to Walailak University, the Fine Arts Department, and their personnel, especially Dittarat Tiprat, Chutharat Chuachin, Sarat Chalawsuntisakul, and Nareerat Leelachat, for always supporting my research. This article is part of the ongoing "Cultural Landscape of the Tambralinga Kingdom" research project funded by the Anandhamahidol Foundation. I would like to dedicate this article to my father, Preecha Noonsuk, and scholars who have studied this area before me.

\section{NOTES}

1. Although I was born and raised in coastal Nakhon Si Thammarat and have a good understanding of its cultural geography, my intimate knowledge extends back only a few decades. I conducted ethnographic interviews and participatory observation to further understand the area's cultural geography. I interviewed local village elders in their seventies and eighties and asked them to recall formative periods of their lives and how their parents and grandparents did things in the past. While I am under 
no illusion that contemporary practices necessarily reflect ancient patterns, there is nevertheless something perennial about the world of small-scale agriculture, dependent on human and animal energy, in which wood and fiber provide housing, and that was for a long time knit together spatially by rivers, small boats, and foot trails, with roads and railways only recently added.

2. Pictures and information about these images were generously provided by Mr. Kitti Chincharoentham, the head curator of the Chaiya National Museum, Surat Thani Province.

3. The reason I focused on brick shrines in my initial phase of field research was because they were most visible on the ground, whereas residential sites were difficult to identify by archaeological survey methods. Ancient communities such as those in the isthmian tract have left behind few imperishable remains other than pottery sherds. Other kinds of sites will be explored in the future, however.

4. The detailed information about the discovery derives from the Fine Arts Department internal report written by Sarat Chalawsuntisakul on 15 May 2013.

5. I took part in an archaeological survey of this area supervised by Professor Miriam Stark in 2003.

\section{REFERENCES CITED}

Aieosriwong, N.

1995 Phunthi nai Khati Thai [Space in Thai conception], in Phakhaoma, Phasin, Kangkengnai lae la: 130-149. Bangkok: Mathichon (in Thai).

Anschuetz, K. F., R. H. Wilshusen, And C. L. Scheick

2001 An archaeology of landscapes: Perspective and directions. Journal of Archaeological Research $9(2): 157-211$.

Bellina-Pryce, B., and P. Silapanth

2006 Weaving cultural identities on Trans-Asiatic networks: Upper Thai-Malay Peninsula-An early socio-political landscape. Bulletin de l'École Française d'Extrême-Orient 93:257-293.

Bishop, P., D. SANDERSON, AND M. STARK

2003 OSL and radiocarbon dating of a pre-Angkorian canal in the Mekong Delta, Southern Cambodia. Journal of Archaeological Science 31(2004):319-336.

Chaisuwan, B.

2011 Early contacts between India and the Andaman Coast in Thailand from the second century to eleventh century CE, in Early Interactions between South and Southeast Asia: 83-112, ed. P.-Y. Manguin, A. Mani, and G. Wade. Singapore: Institute of Southeast Asian Studies.

CMDNST [Committee for Monumental Development at Nakhon Si Thammarat]

1985 The survey reports of archaeological sites in Sichon. Unpublished report. Archived at the Fine Arts Department of Thailand (in Thai).

Dalsheimer, N., And P.-Y. Manguin

1998 Visnu mitrés et réseaux marchands en Asie du Sud-Est: Nouvelles données archéologiques sur le Ier millénair apr. J.-C. Bulletin de L'Ecole Francaise D'Extreme-Orient 85:87-123.

Devereux, Peter

2000 The Sacred Place: The Ancient Origins of Holy and Mystical Sites. London: Cassell \& Co.

FAD [Fine Arts Department]

2003 The Bronze Kettle Drums in Thailand. Bangkok: Fine Arts Department.

Glover, I. C.

1990 Early Trade between India and Southeast Asia: A Link in the Development of a World Trading System. Occasional Paper 16. Hull, U.K.: Centre for South-East Asian Studies, University of Hull.

JacQ-Hergoualc'H, M.

2002 The Malay Peninsula: Crossroads of the Maritime Silk Road (100 BC-1300 AD), trans. V. Hobson. Vol. 13 of Handbook of Oriental Studies, Section 3: Southeast Asia. Leiden: Brill.

LAVY, P.

2014 Conch-on-hip images in Peninsular Thailand and early Vaiṣnava sculpture in Southeast Asia, in Before Siam: Essays in Art and Archaeology: 152-173, ed. Nicolas Revire and Stephen A. Murphy. Bangkok: River Books and Siam Society.

Manguin, P.-Y.

2004 The archaeology of early maritime polities of Southeast Asia, in Southeast Asia: From Prehistory to History: 282-313, ed. Ian Glover and Peter Bellwood. London: Routledge Curzon. 
Midas Consultants Ltd.

1996 Images of Nakhon Si Thammarat Province from past to present, in Settlement Culture in Nakhon Si Thammarat: 1-148, ed. Somphut Thurachen. Nakhon Si Thammarat: Nakhon Si Thammarat Rajabhat University (in Thai).

NoOnsuk, P.

1997 Archaeological Sites in Southern Thailand. Bangkok: Office of the National Research Board (in Thai).

2001 History of Nakhon Si Thammarat: The Development of States on the Thai Peninsula from the Sixth to the Fourteenth Centuries AD. Ph.D. diss. Chulalongkorn University, Bangkok (in Thai).

2004 The Brahmanical Sacred Places. Patani: Prince of Songkhla University (in Thai).

NoOnsuk, P., AND W. NoOnsuk

2003 The discovery of a new Vishnu image in Southeast Asia. Muang Boran 29(2): 90-107 (in Thai with English abstract).

NoOnsuk, W.

2013a Tambralinga and Nakhon Si Thammarat: Early Kingdoms on the Isthmus of Southeast Asia. Nakhon Si Thammarat: Nakhon Si Thammarat Rajabhat University Press.

$2013 b$ The political landscape of the Tambralinga Kingdom. Tai Culture 23:146-159.

O'CONNOR, S. J.

1965 Brahmanical Sculptures of Peninsular Siam. Ph.D. diss. Cornell University, Ithaca, NY.

1972 Hindu Gods of Peninsular Siam. Ascona, Switzerland: Artibus Asiae.

1974 Buddhist votive tablets and caves in peninsular Thailand, in Art and Archaeology in Thailand, in Commemoration of the 100th Anniversary of the National Museum: 67-84. Bangkok: Fine Arts Department.

1986 Introduction, in The Archaeology of Peninsular Siam: 1-10, ed. S. J. O’Connor. Bangkok: Siam Society.

19866 Tambralinga and the Khmer empire, in The Archaeology of Peninsular Siam: 135-149, ed. S. J. O’Connor. Bangkok: Siam Society.

2013 Foreword, in Tambralinga and Nakhon Si Thammarat: Early Kingdoms on the Isthmus of Southeast Asia: xi-xiv, by W. Noonsuk. Nakhon Si Thammarat: Nakhon Si Thammarat Rajabhat University Press.

Sмiтh, A. T.

2003 The Political Landscape: Constellations of Authority in Early Complex Polities. Berkeley: University of California Press.

STARK, M.

2006 Early Mainland Southeast Asian landscapes in the first millennium A.D. Annual Review of Anthropology 35(21): 1-26.

Sumio, F

2004 The long 13th century of Tambralinga: From Javaka to Siam. The Memoirs of the Toyo Bunko $62: 45-79$.

SuphawajRuksakul, A.

2005 Coastal Erosion at the Pak Phanang River Basin, Changwat Nakhon Si Thammarat. M.S. thesis. Chulalongkorn University, Bangkok.

Vallibhotama, S.

2008a Editorial. Muang Boran Journal 34(1):7-10 (in Thai).

$2008 b$ National gross happiness of the Bhutanese and sufficiency of the Thais. Muang Boran Journal 34(2) : 7-10 (in Thai).

2008 c Meanings of Cultural Landscape. Bangkok: Lek-Prapai Foundation (in Thai).

VeERAPrasert, M.

1992 Klong Thom: An ancient bead-manufacturing location and an ancient entrepôt, in Early Metallurgy, Trade and Urban Centres in Thailand and Southeast Asia: 149-161, ed. I. C. Glover, P. Suchitta, and J. Villiers. Bangkok: White Lotus.

Wheatley, P.

1966 The Golden Khersonese. Kuala Lumpur: University of Malaya Press.

Wolters, O. W.

1958 Tambralinga. Bulletin of the School of Oriental and African Studies, University of London 11(3) : 587-607. 
WYATT, D. K.

1975 The Crystal Sands, the Chronicles of Nagara Sri Dharrmaraja. Data Paper No. 98, Southeast Asia Program, Cornell University, Ithaca, NY.

\begin{abstract}
Located on the east coast of peninsular Siam, an isthmian tract between the South China Sea and the Bay of Bengal, Tambralinga had the cosmopolitan openness associated with islands to trade and cultural influences. It was involved in maritime exchange since the late centuries B.C., and its heartland had the highest densities of bronze drums, early Visnu images, lingas, Hindu shrines, and stone inscriptions in peninsular Siam. During its peak in the early centuries of the second millennium A.D., according to historical documents, it sent a series of envoys to China and sent an army across the ocean to occupy the northern part of Sri Lanka. However, its early development and landscape have been less studied. This article explores the relationships between land and life in Tambralinga's heartland, today's Nakhon Si Thammarat Province, during the fifth to thirteenth centuries A.D. As a pioneering work on this topic in peninsular Siam, this article discusses the distributions of late prehistoric sites and early Hindu shrines in relation to geography using data from GIS-based studies, archaeological surveys and excavations, and ethnographic interviews. The results demonstrate that the landscape of Tambralinga was vital to its development. Its heartland opened out to the South China Sea, where an intensive maritime trade took place, and it had mountains in its backyard that were the source of forest products and tin, valued highly by foreign merchants. The floodplain between the shores and the mountains produced rice and cattle for the population of the kingdom. Tambralinga had beach ridges, running in the north-south direction, as the core of its landscape, which facilitated communications among clusters of communities. Rivers and walking trails provided passageways between various ecological zones and connected the kingdom to the west coast of the isthmus as well. KEYwORDS: landscape archaeology, archaeology of Hinduism, peninsular Siam, maritime Southeast Asia, Tambralinga, Nakhon Si Thammarat.
\end{abstract}

